\title{
In vitro antibacterial and time kill evaluation of mononuclear phosphanegold(I) dithiocarbamates
}

Bao-Jing Chen ${ }^{\mathrm{a}}$, Nazzatush Shimar Jamaludin ${ }^{\mathrm{b}}$, Chai-Hoon Khoo ${ }^{\mathrm{a}}$, Tian-Hong See ${ }^{\mathrm{a}}$, Jiun-Horng Sim ${ }^{\mathrm{a}}$, Yoke-Kqueen Cheah ${ }^{\mathrm{a}, *}$, Siti Nadiah Abdul Halim ${ }^{\mathrm{b}}$, Hoi-Ling Seng ${ }^{\mathrm{c}}$, Edward R. T. Tiekink ${ }^{\mathrm{d}, *}$

${ }^{a}$ Department of Biomedical Science, Faculty of Medicine and Health Sciences, University Putra Malaysia, 43400 UPM Serdang, Selangor Darul Ehsan, Malaysia

${ }^{b}$ Department of Chemistry, University of Malaya, 50603 Kuala Lumpur, Malaysia

${ }^{c}$ Department of Biological Sciences, Faculty of Science and Technology, Sunway University, 47500 Bandar Sunway, Selangor Darul Ehsan, Malaysia

${ }^{d}$ Research Centre for Crystalline Materials, Faculty of Science and Technology, Sunway University, 47500 Bandar Sunway, Selangor Darul Ehsan, Malaysia

* Corresponding authors: (Y.-K. Cheah): ykcheah@medic.upm.edu.my; Tel: +60 389472343; Fax: +60 389436178; (E. R. T. Tiekink): E-mail: edwardt@ sunway.edu.my; Tel: +60 37491 7173; Fax: +60 374918633 . 


\section{ABSTRACT}

Four compounds, $\mathrm{R}_{3} \mathrm{PAu}\left[\mathrm{S}_{2} \mathrm{CN}\left(\mathrm{CH}_{2} \mathrm{CH}_{2} \mathrm{OH}\right)_{2}\right], \mathrm{R}=\mathrm{Ph}(1)$ and $\mathrm{Cy}(2)$, and $\mathrm{Et}_{3} \mathrm{PAuS}_{2} \mathrm{CNR}_{2}, \mathrm{R}^{\prime}=$ $\mathrm{R}^{\prime}=\mathrm{Et}(3)$ and $\mathrm{R}_{2}^{\prime}=\left(\mathrm{CH}_{2}\right)_{4}(4)$, have been evaluated for antibacterial activity against a panel of 24 Gram positive (8) and Gram negative (16) bacteria. Based on minimum inhibitory concentration (MIC) scores, compounds 1 and 2 were shown to be specifically potent against Gram positive bacteria whereas compounds 3 and, to a lesser extent, 4 exhibited broad range activity. All four compounds were active against methicillin resistant Staphylococcus aureus (MRSA). Time kill assays revealed the compounds to exhibit both time- and concentration-dependent pharmacokinetics against susceptible bacteria. Each compound was bactericidal against one or more bacteria with 3 being especially potent after $8 \mathrm{~h}$ exposure; compounds 1 and 3 were bactericidal against MRSA. Compound 3 was the most effective bactericide across the series especially toward B. subtilis, S. saprophyticus, A. hydrophilia, P. vulgaris, and $V$. parahaemolyticus. This study demonstrates the potential of this class of compounds as antibacterial agents, either broad range or against specific bacteria.

Keywords:

Phosphanegold(I) compounds Dithiocarbamate Thiolate Antimicrobial Time kill assay

\section{Introduction}

Global dissemination of antibacterial resistance has rendered worldwide health practice vulnerable [1]. Antibacterials are essential in the prevention and treatment of bacterial infection which commonly occurs in surgery, organ transplant, cancer chemotherapy, and in veterinary 
applications [2]. In particular, the emergence of methicillin resistant Staphylococcus aureus (MRSA), vancomycin-resistant enterococci, third-generation cephalosporins resistant Escherichia coli and Klebsiella pneumonia, penicillin resistant Streptococcus pneumoniae, extended spectrum $\beta$-lactamase, and carbapenem-resistant Enterobacteriaceae are prominent examples that are both widespread and of great concern $[3,4]$. The emergence of bacterial resistance to drugs has called into question the effectiveness of current antibacterial chemotherapy. The problem arises in part due to misuse of antimicrobial agents which have created environmental stress for bacteria promoting natural selection therefore contributing to resistance. In order to survive bacteria promote resistance through genetic mutations and extrinsic acquaintance of resistance genes $[5,6]$. Also of major concern over the past two decades is the relatively slow pace associated with the discovery of new classes of drugs and with the lack of exploitation of new generation drugs derived from existing licensed drugs [7]. A further challenge is that multidrug resistant bacteria are becoming ubiquitous in both developed and developing countries $[8,9]$ and that newly discovered antibacterial agents have limited revolutionary mechanisms of action for clinical use [10]. These issues have motivated new strategies and initiatives launched by the Infectious Diseases Society of America (Policy), Action on Antibiotic Resistance (ReAct) [2,11], and The British Society for Antibiotic Chemotherapy (BSAC) [12] with the purpose of improving research and development of new antibacterial drugs.

Metallopharmaceuticals relates to the use of metal based species in the treatment of various illnesses and highlights the importance of medicinal inorganic chemistry [13]. A prominent element in this context is gold [14-20]. While the clinical use of gold compounds for the treatment of rheumatoid arthritis and the development of both gold(I) and gold(III) compounds as anti-cancer 
agents is well documented, their investigation as potential antimicrobial agents is emerging and has only recently been the subject of a comprehensive review [21]. Auranofin ${ }^{\circledR}$, an orally administered disease modifying anti-rheumatic drug (DMARD), is a relatively late comer in the treatment of rheumatoid arthritis $[14,15]$ but might be a good example of "drug repurposing/repositioning" whereby a clinically approved drug might find applications against other disease [22]. Indeed, auranofin ${ }^{\circledR}$ displays anticancer potential [23] and more recent studies indicate prospective antimicrobial applications [24]. The key structural feature of auranofin ${ }^{\circledR}$ is a linear $\mathrm{P}-\mathrm{Au}-\mathrm{S}$ geometry defined by phosphane and thiolate ligands [25]. The increasing interest in the antiproliferative activity of auranofin ${ }^{\circledR}$ builds upon investigations of a full range of gold(I) and gold(III) compounds [26-28], a good number of which contain the $\mathrm{P}-\mathrm{Au}-\mathrm{S}$ chromophore with thiolates such as mercaptopurinate [29-31], isomeric mercaptobenzoates [32,33], thiobenzoate [34] and, pertinent to the present investigation, 1,1-dithiolates such as dithiocarbamates and xanthates [35]. In keeping in with the wide range of biological activities exhibited by metal (incorporating transition and main group elements) dithiocarbamates [36], a relatively large number of studies have been conducted on phosphanegold(I) dithiocarbamates [37-41], including the determination of biological targets and mechanisms of cell death. Given the emerging interest in the antimicrobial activity of gold compounds [36] and the knowledge that certain metal dithiocarbamates exhibit anti-microbial activity [21], recently a series of phosphanegold(I) dithiocarbamates, namely $\mathrm{R}_{3} \mathrm{PAu}\left[\mathrm{S}_{2} \mathrm{CN}(\mathrm{iPr}) \mathrm{CH}_{2} \mathrm{CH}_{2} \mathrm{OH}\right]$ for $\mathrm{R}=\mathrm{Et}, \mathrm{Cy}$ and $\mathrm{Ph}$, were investigated for antimicrobial activity against a panel of 25 strains of Gram-positive and Gram-negative bacteria [42]. While the $\mathrm{R}=\mathrm{Et}$ compound had broad range activity against both Gram-positive and Gram-negative bacteria, the $\mathrm{R}=\mathrm{Cy}$ and $\mathrm{Ph}$ compounds exhibited specific activity against Gram-positive bacteria. Especially noteworthy was that the $\mathrm{R}=$ Et compound was potent toward 
MRSA. Time-kill studies indicated the $\mathrm{R}=\mathrm{Cy}$ and $\mathrm{Ph}$ compounds were bactericidal whereas the $\mathrm{R}=$ Et compound was both bactericidal and bacteriostatic depending on the specific bacterial strain, observations suggesting different mechanisms of action are applicable depending on both the nature of the phosphane ligand and bacteria. Given that earlier studies showed the $\mathrm{Et}_{3} \mathrm{P}$ ligand in gold compounds [43] and $-\mathrm{S}_{2} \mathrm{CN}\left(\mathrm{CH}_{2} \mathrm{CH}_{2} \mathrm{OH}\right)_{2}$ ligands in copper and silver compounds [44] furnish active species, the foregoing studies were extended to the four compounds shown in Fig. 1. Herein, a study evaluating the potency of 1-4 against a panel of 24 Gram-positive and Gramnegative clinical bacteria is reported. The minimum inhibitory concentration (MIC) and minimum bactericidal concentration (MBC) have been determined as well as preliminary pharmacokinetics (time kill assays).

\section{Experimental}

\subsection{Materials}

Reactions were carried out under ambient conditions; all chemicals and solvents were used as received. The $\mathrm{R}_{3} \mathrm{PAuCl}$ precursors were synthesized by reducing $\mathrm{HAuCl}_{4}$ (Sigma-Aldrich) with sodium sulfite followed by addition of the respective phosphane ligand, i.e., $\mathrm{Ph}_{3} \mathrm{P}$ (Merck), $\mathrm{Cy} 3 \mathrm{P}$ (Acros), and $\mathrm{Et}_{3} \mathrm{P}$ (Sigma-Aldrich). The dithiocarbamate salts were prepared in quantitative yields from the reaction of the respective amine with $\mathrm{KOH}$ or $\mathrm{NaOH}$ and $\mathrm{CS}_{2}$, following literature precedents [45]; [ $\left.\mathrm{NH}_{4}\right]\left[\mathrm{S}_{2} \mathrm{CN}\left(\mathrm{CH}_{2}\right)_{4}\right]$ was purchased from Fisher.

\subsection{Instrumentation}


Melting points were determined on a Mel-Temp II melting point apparatus. Elemental analyses were performed on a Perkin Elmer PE 2400 CHN Elemental Analyser. IR spectra were obtained by an Attenuated Total Reflectance (ATR) technique on a Perkin Elmer Spectrum 2000 RX1 FTIR spectrophotometer; abbreviations: $\mathrm{s}=$ strong, $\mathrm{m}=$ medium, $\mathrm{w}=$ weak and $\mathrm{sh}=$ shoulder. ${ }^{1} \mathrm{H}$ and ${ }^{13} \mathrm{C}\left\{{ }^{1} \mathrm{H}\right\}$ NMR spectra were recorded in $\mathrm{CDCl}_{3}$ solution at $25{ }^{\circ} \mathrm{C}$ on JOEL LA and JOEL Lambda $400 \mathrm{MHz}$ NMR spectrometers with chemical shifts referenced to the residual proton of $\mathrm{CDCl}_{3} .{ }^{31} \mathrm{P}\left\{{ }^{1} \mathrm{H}\right\} \mathrm{NMR}$ spectra were recorded in $\mathrm{CDCl}_{3}$ solution at $25^{\circ} \mathrm{C}$ on a Bruker Avance 400 MHz NMR spectrometer with the chemical shifts recorded relative to $85 \%$ aqueous $\mathrm{H}_{3} \mathrm{PO}_{4}$ as external reference; abbreviations for NMR assignments: $s$, singlet; $d$, doublet; $t$, triplet; $q$, quartet; $m$, multiplet.

\subsection{Synthesis and characterization}

\subsubsection{Triphenylphosphanegold(I) (N,N-dihydroxyethyldithiocarbamate) (1)}

$\mathrm{K}\left[\mathrm{S}_{2} \mathrm{CN}\left(\mathrm{CH}_{2} \mathrm{CH}_{2} \mathrm{OH}\right)_{2}\right](0.20 \mathrm{~g}, 1 \mathrm{mmol})$ in water $(30 \mathrm{ml})$ was added dropwise to a suspension of $\mathrm{Ph} 3 \mathrm{PAuCl}(0.49 \mathrm{~g}, 1 \mathrm{mmol})$ in acetone $(5 \mathrm{ml})$. The solution was stirred for $1 \mathrm{~h}$ to give a yellow gum. Water was decanted and after several washings with water, the gum was dissolved in a minimum volume of methanol and this was added dropwise into diethylether $\left(\begin{array}{ll}1 & 1\end{array}\right)$ while stirring vigorously until precipitation occurred. The yellow precipitates were separated using a separating funnel. The yellow precipitate that deposited at the bottom of the separating funnel was isolated and allowed to dry at room temperature. Yield: $66 \%$. M.Pt: $150.0{ }^{\circ} \mathrm{C} .{ }^{1} \mathrm{H}$ NMR: $\delta$ 7.45-7.58 $\left(15 \mathrm{H}, \mathrm{m}\right.$, aryl-H); $4.22\left(4 \mathrm{H}, t, \mathrm{NCH}_{2}, J=6 \mathrm{~Hz}\right) ; 4.10\left(4 \mathrm{H}, t, \mathrm{CH}_{2} \mathrm{O}, J=6 \mathrm{~Hz}\right)$ ppm; $\mathrm{OH}$ not observed. ${ }^{13} \mathrm{C}\left\{{ }^{1} \mathrm{H}\right\}$ NMR: $\delta 209.9$ (CS); 128.5-134.2 (aryl-C); $61.2\left(\mathrm{CH}_{2} \mathrm{O}\right) ; 59.5$ $\left(\mathrm{NCH}_{2}\right)$ ppm. ${ }^{31} \mathrm{P}\left\{{ }^{1} \mathrm{H}\right\}$ NMR: $\delta 34.56$ ppm. IR $\left(\mathrm{cm}^{-1}\right): 1436(\mathrm{sh}, \mathrm{m}) v(\mathrm{C}-\mathrm{N}) ; 1027(\mathrm{w}), 997$ (sh, 
m) $v(\mathrm{C}-\mathrm{S})$. Anal. Calc. for $\mathrm{C}_{23} \mathrm{H}_{25} \mathrm{AuNO}_{2} \mathrm{PS}_{2}$ : C, 41.25; H, 3.46; N, 2.29\%. Found: C, 41.65; H, $3.65 ; \mathrm{N}, 2.01 \%$.

\subsubsection{Tricyclohexylphosphanegold(I) (N,N-dihydroxyethyldithiocarbamate) (2)}

Compound 2 was prepared as for $\mathbf{1}$ but using $\mathrm{Cy}_{3} \mathrm{PAuCl}$ as the precursor. Yield: $67 \%$. M.Pt: $162.5{ }^{\circ} \mathrm{C} .{ }^{1} \mathrm{H}$ NMR: $\delta 4.20\left(4 \mathrm{H}, t, \mathrm{NCH}_{2}, J=6 \mathrm{~Hz}\right) ; 4.08\left(4 \mathrm{H}, t, \mathrm{OCH}_{2}, J=6 \mathrm{~Hz}\right) ; 3.37(2 \mathrm{H}, s$, $\mathrm{OH}) ; 1.26-2.02(33 \mathrm{H}, \mathrm{m}, \mathrm{Cy}-\mathrm{H}) \mathrm{ppm} .{ }^{13} \mathrm{C}\left\{{ }^{1} \mathrm{H}\right\} \mathrm{NMR}: \delta 210.5(\mathrm{CS}) ; 61.3\left(\mathrm{CH}_{2} \mathrm{O}\right) ; 59.1\left(\mathrm{NCH}_{2}\right)$; 33.4 (CHP); $30.6\left(\underline{\mathrm{CH}}_{2} \mathrm{CHP}\right) ; 27.1\left(\underline{\mathrm{CH}}_{2} \mathrm{CH}_{2} \mathrm{CHP}\right) ; 26.0\left(\underline{\mathrm{CH}}_{2} \mathrm{CH}_{2} \mathrm{CH}_{2} \mathrm{CHP}\right)$ ppm. ${ }^{31} \mathrm{P}\left\{{ }^{1} \mathrm{H}\right\}$ NMR: $\delta 55.42$ ppm. IR $\left(\mathrm{cm}^{-1}\right): 1458(\mathrm{~m}) \mathrm{v}(\mathrm{C}-\mathrm{N}) ; 1065(\mathrm{~s}), 985(\mathrm{sh}, \mathrm{m}) \mathrm{v}(\mathrm{C}-\mathrm{S})$. Anal. Calc. for $\mathrm{C}_{23} \mathrm{H}_{43} \mathrm{AuNO}_{2} \mathrm{PS}_{2}: \mathrm{C}, 40.06 ; \mathrm{H}, 6.24 ; \mathrm{N}, 2.22 \%$. Found: C, 40.46; H, 6.64; N, $2.62 \%$.

\subsubsection{Triethylphosphanegold(I) (N,N-diethyldithiocarbamate) (3)}

$\mathrm{Na}\left[\mathrm{S}_{2} \mathrm{CNEt}_{2}\right](0.14 \mathrm{~g}, 1 \mathrm{mmol})$ was dissolved in water $(20 \mathrm{ml})$ and added dropwise to a suspension of $\mathrm{Et}_{3} \mathrm{PAuCl}(035 \mathrm{~g}, 1 \mathrm{mmol})$ in acetone $(10 \mathrm{ml})$. The solution was stirred for $1 \mathrm{~h}$ after which a bright-yellow gum was obtained. Solvent extraction with chloroform/water (3:1) followed. The chloroform layer was filtered off, dried over $\mathrm{Na}_{2} \mathrm{SO}_{4}$, and allowed to dry at room temperature to yield a yellow crystals [35]. Yield: $80 \%$. M.Pt: $91.2{ }^{\circ} \mathrm{C} .{ }^{31} \mathrm{P}\left\{{ }^{1} \mathrm{H}\right\}$ NMR: $\delta 33.99 \mathrm{ppm}$. IR (cm

$\left.{ }^{1}\right): 1484$ (sh, s) v(C-N); 1047 (sh, s), 982 (sh, s) v(C-S). Anal. Calc. for $\mathrm{C}_{11} \mathrm{H}_{25} \mathrm{AuNPS}_{2}$ : C, 28.51; H, 5.44; N, 3.02\%. Found: 28.91; H, 5.10; N, 3.42\%.

\subsubsection{Triethylphosphanegold(I) (N,N-pyrrolidinedithiocarbamate) (4)}

Compound 4 was prepared and recrystallized as for 3 but using $\mathrm{NH}_{4}\left[\mathrm{~S}_{2} \mathrm{CN}\left(\mathrm{CH}_{2}\right)_{4}\right]$. Yield: 895\%. M.Pt: $76.2{ }^{\circ} \mathrm{C} .{ }^{1} \mathrm{H}$ NMR: $\delta 3.76\left(4 \mathrm{H}, t, \mathrm{NCH}_{2}, J=8 \mathrm{~Hz}\right) ; 1.93\left(4 \mathrm{H}, t, \mathrm{NCH}_{2} \mathrm{CH}_{2}, J=8\right.$ $\mathrm{Hz}) ; 1.77\left(6 \mathrm{H}, d q, \mathrm{PCH}_{2}, J=8,4 \mathrm{~Hz}\right) ; 1.17\left(9 \mathrm{H}, d t, \mathrm{PCH}_{2} \underline{\mathrm{H}}_{3}, J=8,4 \mathrm{~Hz}\right) \mathrm{ppm} .{ }^{13} \mathrm{C}\left\{{ }^{1} \mathrm{H}\right\} \mathrm{NMR}:$ 
$\delta 202.1(\mathrm{CS}) ; 53.5\left(\mathrm{NCH}_{2}\right) ; 25.6\left(\mathrm{NCH}_{2} \underline{\mathrm{CH}}_{2}\right) ; 17.8\left(\mathrm{PCH}_{2}\right) ; 8.5\left(\mathrm{PCCH}_{3}\right)$ ppm. ${ }^{31} \mathrm{P}\left\{{ }^{1} \mathrm{H}\right\} \mathrm{NMR}: \delta$ 34.31 ppm. IR $\left(\mathrm{cm}^{-1}\right): 1432(\mathrm{~s}, \mathrm{~m}) \mathrm{v}(\mathrm{C}-\mathrm{N}) ; 1040$ (s, sh), 999 (s, sh) v(C-S). Anal. Calc. for $\mathrm{C}_{11} \mathrm{H}_{23} \mathrm{AuNPS}_{2}$ : C, 28.64; H, 5.02; N, 3.04\%. Found: 29.04; H, 5.06; N, 2.93\%.

\subsection{Anti-bacterial activity studies}

\subsubsection{Preparation of Test Organism}

A total of 24 clinically important pathogens were used in this study and these were purchased from American Type Culture Collection (ATCC). This included eight Gram-positive and 16 Gramnegative bacteria. The bacteria were Enterococcus faecalis (ATCC 29212), Enterococcus faecium (ATCC 19434), Bacillus cereus (ATCC 10876), Bacillus subtilis (ATCC 6633), Staphylococcus aureus (ATCC 25923), Staphylococcus aureus MRSA (ATCC 43300), Staphylococcus saprophyticus (ATCC 15305), Listeria monocytogenes (ATCC 19117), Enterobacter cloacae (ATCC 35030), Enterobacteraerogenes (ATCC 13048), Salmonella typhimurium (ATCC 14028), Salmonella paratyhi A (ATCC 9150), Shigellasonnei (ATCC 9290), Shigellaflexneri (ATCC 12022), Pseudomonas aeruginosa (ATCC 27853), Klebsiellapneumoniae (ATCC 700603), Vibrio parahaemolyticus (ATCC 17802), Proteus mirabilis (ATCC 25933), Acinetobacterbaumannii (ATCC 19606), Proteus vulgaris (ATCC 13315), Stenotrophomonasmaltophilia (ATCC 13637),

Citrobacterfreundii (ATCC 8090), Escherichia coli (ATCC 25922), and Aeromonashydrophila(ATCC 35654). Colonies of each bacterial strain were picked from cultures grown on agar plates and inoculated into Mueller-Hinton broth (MHB) (Difco) to prepare the inoculum suspension. 


\subsubsection{Disk Diffusion}

A concentration of $2 \mathrm{mg} / \mathrm{ml}$ of each test compound was used in this study using DMSO as the solvent. According to the Clinical and Laboratory Standards Institute (CLSI) guidelines, bacterial suspensions with density corresponding to a McFarland 0.5 turbidity standard, which corresponds to $10^{8} \mathrm{CFU} / \mathrm{ml}$, was swabbed onto Mueller-Hinton agar (MHA) (Difco) with a sterile cotton swab. Six sterile filter paper discs of $6 \mathrm{~mm}$ were applied on each MHA and an anti-biotic treated disc, the positive control, was placed in the center of the agar. For each test compound, $5 \mu$ l solution was dropped on the filter paper disc. Similar volumes of MHB, which served as the negative control, and DMSO (Merck), as the solvent control, were also dropped on another two blank discs. Each plate was then incubated for $24 \mathrm{~h}$ at $37^{\circ} \mathrm{C}$ or $30^{\circ} \mathrm{C}$ incubators depending on the optimum growth conditions of each bacterium. Each determination was performed in triplicate. The diameter of the inhibition zone produced by each bacterial strain representing antibacterial activity was measured in millimeter and interpreted with CLSI standard interpretative criteria (CLSI, 2012).

\subsubsection{MIC and MBC determination}

The broth micro-dilution method was used to define the potency of the test compounds by determining the lowest concentration required to hinder bacterial growth (minimum inhibitory concentration, MIC) or to completely kill the bacterium (minimum bactericidal concentration, MBC). MIC determination was performed in accordance with the recommended CLSI protocols. Test compounds were prepared by two-fold serial dilutions to achieve final concentrations ranging from 100 to $0.003 \mu \mathrm{g} / \mathrm{ml}$. Each test compound $(5 \mu \mathrm{l})$ was then added into wells of 96-well microplates containing $10^{5} \mathrm{CFU} / \mathrm{ml}$ of exponentially growing bacterial cells. Controls were also 
included in each microplate comprising DMSO (solvent control), MHB (negative control), standard antibiotics, i.e., tetracycline or chloramphenicol (positive control), and bacterial cells only. The microplates were subsequently incubated for $24 \mathrm{~h}$ at $37^{\circ} \mathrm{C}$ or $30^{\circ} \mathrm{C}$. Each test was performed in triplicate. As an indicator of bacterial growth, $50 \mu 1$ of $0.2 \mathrm{mg} / \mathrm{ml} \mathrm{p}$-iodonitrotetrazolium violet (Sigma-Aldrich) was added into each well and the microplates were further incubated for at least 30 mins under aerobic agitation. The presence of bacterial activity converts the dye from colorless to purple. The MIC was determined as the lowest concentration at which there was no trace of purple. After MIC determination, the MBC was determined by subculture of $100 \mu 1$ aliquots from each well with no visible growth on MHA followed by incubating overnight at $37{ }^{\circ} \mathrm{C}$. $\mathrm{MBC}$ endpoint was defined as the lowest concentration of the compounds that kills more than $99.9 \%$ of bacteria which is taken to represent no bacterial growth on agar.

\subsubsection{Time-kill assay}

Further to the evaluation of antibacterial activity, a time kill assay was performed with macrodilution according to the method recommended by CLSI. Bacterial cells in the exponential growth phase were cultured and diluted to approximately $10^{5} \mathrm{CFU} / \mathrm{ml}$. Solutions $(100 \mu \mathrm{l})$ of test compounds with concentrations corresponding to $1 / 2 \mathrm{MIC}$, MIC and $2 \mathrm{MIC}$ were added into the inoculum suspension. MHB inoculated with each bacterial strain without test compound acted as the control in this experiment. The inoculum cultures were incubated at $37^{\circ} \mathrm{C}$ on an orbital shaker at $200 \mathrm{rpm}$. Samples $(200 \mu \mathrm{l})$ were removed from each inoculum culture at time points $0,1,2,3$, 4,8 , and $24 \mathrm{~h}$, ten-fold serially diluted in $0.9 \%$ normal saline and $25 \mu \mathrm{l}$ subcultured from each dilution on MHA. Viable counts were calculated in the units of cfu/ml and kill curves were plotted with time (h) against logarithm of the viable count ( $\left.\log _{10} \mathrm{CFU}\right)$. Each experiment was carried out 
in triplicate and analyzed with mean variables. Bactericidal effects of a compound were seen when $\geq 3 \log _{10}$ decrease in viable colony relative to initial inoculum [46].

\section{Results and discussion}

\subsection{Chemistry}

Four phosphanegold(I) dithiocarbamate compounds, 1-4, have been prepared for antimicrobial assays in the present study, Fig. 1. While 1 and 2, with hydroxyethyl functionalized dithiocarbamate ligands and 4 are new, 3 is a known compound [35] and the crystal structure of 3 is available [47]. A number of studies are now available suggesting that dithiocarbamate ligands with hydroxyethyl groups possess biological activity $[43,44,48,49]$ and therefore it was thought of interest to extend the studies to 1 and 2 , given the anti-bacterial activity of $\mathrm{R}_{3} \mathrm{PAu}\left[\mathrm{S}_{2} \mathrm{CN}(\mathrm{iPr}) \mathrm{CH}_{2} \mathrm{CH}_{2} \mathrm{OH}\right]$ for $\mathrm{R}=\mathrm{Et}$, $\mathrm{Cy}$ and $\mathrm{Ph}$ [42]. Compounds 3 and 4 were included in the present study as they contain $\mathrm{Et}_{3} \mathrm{P}$, as in Auranofin ${ }^{\circledR}$, and have conventional dithiocarbamate ligands which have demonstrated biological activity when complexed to metals [36]. The spectroscopic characteristics are as expected and confirm the anticipated compositions, Fig. 1. While crystal structures were not obtained for 1,2 , or 4 , despite best efforts, it is expected based on literature precedents of mononuclear phosphanegold(I) dithiocarbamates [39,41,47,50-56], that each of 1,2 , and 4 feature a linear $\mathrm{P}-\mathrm{Au}-\mathrm{S}$ geometry arising from an essentially monodentate mode of coordination of the dithiocarbamate ligand. Finally, the stability of $1-4$ in d6-DMSO solution was monitored by ${ }^{1} \mathrm{H}$ over a week. No discernible changes were noted in any of the spectra suggesting the compounds remain intact over the time-scale of the biological assays. 


\subsection{Antibacterial activity}

The in vitro effects of 1-4 on 8 Gram-positive and 16 Gram-negative pathogens were evaluated using the disk diffusion method with results summarized in Table 1. The ${ }^{-} \mathrm{S}_{2} \mathrm{CN}\left(\mathrm{CH}_{2} \mathrm{CH}_{2} \mathrm{OH}\right)_{2}$ anion, as in 1 and 2 , showed no activity against any of the bacteria. Similarly the ${ }^{-} \mathrm{S}_{2} \mathrm{CNEt}_{2}$ anion showed poor activity, having effects on two Gram positive bacteria only and no effect on Gram negative bacteria. By contrast, the ${ }^{-} \mathrm{S}_{2} \mathrm{CN}\left(\mathrm{CH}_{2}\right)_{4}$ anion proved mildly active to all but two of the Gram positive bacteria and to five of the Gram negative bacteria evaluated. Attention is next turned to the phosphanegold(I) compounds of these anions.

Despite having no activity itself, when the ${ }^{-} \mathrm{S}_{2} \mathrm{CN}\left(\mathrm{CH}_{2} \mathrm{CH}_{2} \mathrm{OH}\right)_{2}$ anion is complexed as in 1 and 2, specific but modest activity is seen toward Gram positive bacteria, with 1 tending to be marginally more potent than 2 . The trend toward greater potency upon complexation of the dithiocarbamate ligands is also evident for 3 and 4 but, unlike 1 and 2, 3 and 4 display broad range activity. For 3, significantly enhanced activity against all Gram positive bacteria cf. the free anion was observed. Against Gram negative pathogens 3 proved active against all the bacteria. Generally 3 proved more potent against Gram positive bacteria being most active against $S$. saprophyticus $(29 \mathrm{~mm})$ and least against E. faecium $(20 \mathrm{~mm})$ whereas against Gram negative bacteria, greatest activity was noted against $S$. flexneri $(17 \mathrm{~mm})$ and least against $K$. pneumonia and $P$. aeruginosa $(8 \mathrm{~mm})$.

For 4, significantly enhanced activity against all Gram positive bacteria, cf. the free anion, was also noted. Compound 4 proved active against all the Gram negative bacteria susceptible to the free anion but was more potent against all except against $C$. freundii, i.e., $17 \mathrm{cf} .9 \mathrm{~mm}$ for the 
anion and 4, respectively. This being stated, differences in potency between the free anion and 4 were generally small except against $C$. freundii, i.e., 9 cf. $26 \mathrm{~mm}$, respectively. Compound 4 also showed activity against five Gram negative bacteria not susceptible to the anion. Potency was greater against Gram positive bacteria, e.g., S. saprophyticus $(30 \mathrm{~mm})$ and E. faecium $(21 \mathrm{~mm})$, mirroring the trend for 3. With the exception of $S$. aureus, i.e., 26 and $24 \mathrm{~mm}$, respectively, 4 was consistently more potent than 3 although differences are small. While 4 was also active against 10 Gram negative bacteria, the potency was the same (P. vulgaris) or reduced cf. 3. Finally, while 3 and 4 displayed a broader spectrum of activity, the observation of their reduced potency against Gram negative bacteria is probably related to the presence of the outer wall membrane which functions as an additional protective layer that restricts the influx of the trial compounds $[57,58]$.

\subsection{Determination of minimum inhibitory concentration and minimum bactericidal} concentration

Having established zones of inhibition, Table 1, attention was next directed toward ascertaining the minimum inhibitory concentration (MIC) of the anions and 1-4 against susceptible strains; data are summarized in Table 2. MIC values for the $-\mathrm{S}_{2} \mathrm{CNEt}_{2}$ anion were $>100 \mathrm{mg} / \mathrm{ml}$ or not determinable indicating no antibacterial activity. For the ${ }^{-} \mathrm{S}_{2} \mathrm{CN}\left(\mathrm{CH}_{2}\right)_{4}$ anion, smaller values were observed with 3.125 (C. freundii), 6.25 (B. cereus), and all remaining susceptible strains having MIC >12.5. Significantly lower MIC values were observed for 1-4, again consistent with the pivotal role of the phosphanegold(I) entity in generating antibacterial agents.

For 1 , MIC values ranged from $0.39 \mu \mathrm{g} / \mathrm{ml}$ (B. cereus) to $6.25 \mathrm{mg} / \mathrm{ml}$ (E. faecalis) and for 2 , from $1.56 \mathrm{mg} / \mathrm{ml}$ (B. cereus and L. monocytogenes) to $50.00 \mu \mathrm{g} / \mathrm{ml}$ (S. aureus), suggesting the greater efficacy of the $\mathrm{Ph}_{3} \mathrm{P}$ phosphane ligand over $\mathrm{Cy}_{3} \mathrm{P}$ in these compounds. As a general trend, 
the MIC values against each Gram positive bacterium effected by 3 and 4 were considerably lower than for effected by 1 and 2. With the exception of MIC values for L. monocytogenes $(0.20 \mu \mathrm{g} / \mathrm{ml})$ and each of E. faecalis and E. faecium $(0.39 \mu \mathrm{g} / \mathrm{ml}), 3$ induced MIC values of $0.10 \mu \mathrm{g} / \mathrm{ml}$ in the remaining Gram-positive bacteria. A wider range of MIC values were evident for 4, ranging from a low $0.05 \mu \mathrm{g} / \mathrm{ml}$ against $B$. subtilis to $0.39 \mu \mathrm{g} / \mathrm{ml}$ against $E$. faecium. Differences between 3 and 4 were seen against $B$. subtilis ( 0.10 vs. $0.05 \mu \mathrm{g} / \mathrm{ml}$ ) and E. faecalis ( 0.39 vs. $0.20 \mu \mathrm{g} / \mathrm{ml})$. More variety was noted when Gram negative bacteria were subjected to 3 and 4 . Against $S$. sonnei, the MIC for 3 was greater than that for 4 (3.13 vs $1.56 \mu \mathrm{g} / \mathrm{ml})$, the values were the same against each of A. baumannii, P. vulgaris, and V. parahaemolyticus, and were reduced against the remaining pathogens, Table 2. From the foregoing, a general trend may be seen whereby 4 is slightly more active than 3 against Gram positive bacteria but, 3 exhibits broad range activity against Gram negative bacteria.

Given that inhibition of bacterial growth does not necessarily imply a trial compound can kill a particular bacterium [59], the minimum bactericidal concentration (MBC) was determined in order to identify whether the trial compound was able to kill the bacterium (bactericidal) or simply inhibited growth (bacteriostatic). In light of the increasing bacterial resistance to Gram positive antibiotics, the development of bactericides is a priority over inhibition and subsequent regrowth [60]. The definition of MBC by Levison [61] is employed herein. A compound is considered a bactericidal agent if the MBC value is $\leq 4 \mathrm{x}$ MIC. Conversely, a compound is bacteriostatic if the MBC $>4 \mathrm{x}$ MIC. From the data collated in Table 2, it is evident that 1 is bactericidal against all Gram positive bacteria with the exception of E. faecium. Compound 2 is also bacteriostatic toward E. faecium as well as to S. saprophyticus, being bactericidal to the 
remaining six bacteria, notably MRSA. Quite distinctive behaviour differentiates 3 and 4. Against Gram positive bacteria, 3 is bactericidal against all but E. faecium. By contrast, 4 is bactericidal toward L. monocytogenes, S. aureus, and S. saprophyticus only. Against Gram negative bacteria, 3 is generally bactericidal, killing all tested bacteria except $K$. pneumonia, $P$. aeruginosa, and $S$. maltophilia. Finally, 4 was bactericidal against five Gram negative bacteria, namely $A$. hydrophilla, S. flexneri, S. sonnei, P. vulgaris, and V. parahaemolyticus.

In summary, 3 exhibits broad range antibacterial activity toward both Gram positive and Gram negative bacteria and is generally bactericidal.

\subsection{Time kill assay}

Apart from MBC determination a time kill based approach is a useful model to describe the pharmacodynamics of a trial compound [62]. By contrast to MIC determination, which investigates the antimicrobial effect at one concentration after a specific time, the time kill assay involves evaluating the effect of different concentrations, i.e., $2 \mathrm{x}, 1 \mathrm{x}$, and $0.5 \mathrm{x}$ MIC, over $24 \mathrm{~h}$ incubation. Following CLSI protocols, a $3 \log _{10} \mathrm{CFU} / \mathrm{ml}$ or greater reduction in the viability of the bacterial colony is the point of differentiation between bactericidal and bacteriostatic activity (lower values).

The time-kill curves for 1 and 2 are shown in Figs. 2 and 3, respectively, and data are given in Table 3. At doses of the $1 \mathrm{x}$ MIC value, 1 was bactericidal toward B. cereus $\left(-5.1 \log _{10} \mathrm{CFU} / \mathrm{ml}\right)$ after $1 \mathrm{~h}$, and after $2 \mathrm{~h}$ toward B. subtilis $\left(-3.3 \log _{10} \mathrm{CFU} / \mathrm{ml}\right)$ being bacteriostatic against the other bacteria. Differential $1 \times$ MIC behavior was observed for 2 as this was bactericidal after $1 \mathrm{~h}$ 
application in B. subtilis $\left(-5.1 \log _{10} \mathrm{CFU} / \mathrm{ml}\right)$ and MRSA $\left(-5.4 \log _{10} \mathrm{CFU} / \mathrm{ml}\right)$, and after $2 \mathrm{~h}$ in $E$. faecalis $\left(-3.3 \log _{10} \mathrm{CFU} / \mathrm{ml}\right)$. At $2 \times$ MIC 1 was bactericidal toward B. cereus $\left(-5.1 \log _{10} \mathrm{CFU} / \mathrm{ml}\right)$ and B. subtilis $\left(-3.1 \log _{10} \mathrm{CFU} / \mathrm{ml}\right)$ after $1 \mathrm{~h}$, and after $4 \mathrm{~h}$ MRSA $\left(-5.4 \log _{10} \mathrm{CFU} / \mathrm{ml}\right)$. Under the same conditions, 2 exhibited bactericidal effects after $1 \mathrm{~h}$ toward B. cereus (-5.1 $\left.\log _{10} \mathrm{CFU} / \mathrm{ml}\right), B$. subtilis (-5.1 $\left.\log _{10} \mathrm{CFU} / \mathrm{ml}\right), \mathrm{MRSA}\left(-5.4 \log _{10} \mathrm{CFU} / \mathrm{ml}\right)$, and $S$. saprophyticus $\left(-4.9 \log _{10} \mathrm{CFU} / \mathrm{ml}\right)$; 2 h: E. faecalis $\left(-5.7 \log _{10} \mathrm{CFU} / \mathrm{ml}\right)$, and 8 h: S. aureus $\left(-4.6 \log _{10} \mathrm{CFU} / \mathrm{ml}\right)$. At $1 / 2 \mathrm{x} \mathrm{MIC}, 1$ was uniformly bacteriostatic but 2 was bactericidal against both $B$. subtilis $\left(-5.1 \log _{10} \mathrm{CFU} / \mathrm{ml}\right)$ and MRSA (-5.4 $\left.\log _{10} \mathrm{CFU} / \mathrm{ml}\right)$ after $1 \mathrm{~h}$ administration.

The time kill curves for 3 and 4 are shown in Figs. 4 and 5, respectively, and data are given in Table 4. In the timeframe of the experiments and at $2 \times$ MIC, 3 was bactericidal against all bacteria with the notable exceptions of E. faecium, $K$. pneumonia, $P$. aeruginosa, and $S$. maltophilia. As a general observation, bactericidal effects were noted only after $8 \mathrm{~h}$ administration in most bacteria; $3 \mathrm{~h}$ for $E$. coli and $4 \mathrm{~h}$ for $A$. baumannii. The remaining bacteria were killed by 3 after 1 h: B. subtilis (-5.1 $\left.\log _{10} \mathrm{CFU} / \mathrm{ml}\right)$, S. saprophyticus (-5.0 $\left.\log _{10} \mathrm{CFU} / \mathrm{ml}\right)$, A. hydrophilia (-5.8 $\left.\log _{10} \mathrm{CFU} / \mathrm{ml}\right)$, P. vulgaris (-6.0 $\left.\log _{10} \mathrm{CFU} / \mathrm{ml}\right)$, and $V$. parahaemolyticus $\left(-5.6 \log _{10} \mathrm{CFU} / \mathrm{ml}\right)$. One of these, i.e., P. vulgaris, was also susceptible at $1 / 2 \times$ MIC after $1 \mathrm{~h}$ while at this dose $B$. subtilis and V. parahaemolyticus were killed after $2 \mathrm{~h}$, and $4 \mathrm{~h}$ was required for $S$. saprophyticus; at $1 \frac{2}{2}$ x MIC 3, was bacteriostatic toward A. hydrophilia.

Consistent with the MBC results, 4 was bacteriostatic against most of the bacteria. The most promising activity was seen against $S$. saprophyticus $\left(-5.0 \log _{10} \mathrm{CFU} / \mathrm{ml}\right)$ but at $2 \times$ MIC after $8 \mathrm{~h}$ exposure. 
From the foregoing, it is evident that a greater killing rate was observed in susceptible bacteria with the egress of time. Also, a concentration dependence was seen. Detectable regrowth of bacteria was noted for 1 and 2 but, generally not for bacteria treated with 3 and 4 , behavior that may be correlated with selective development of resistant- and killing-susceptible subpopulations $[46,63]$.

\section{Conclusions}

Phosphanegold(I) dithiocarbamate compounds 1-4 and literature precedents [42] offer prospects as antimicrobial agents displaying time- and concentration-dependent bactericidal activity against a range of Gram positive and Gram negative bacteria. In terms of a structure activity relationship based on the present and literature study [42], i) species with hydroxyethylsubstituted dithiocarbamate ligands are generally less promising than their all alkyl counterparts, and ii) compounds with triethylphosphane ligands are more potent than phenyl and cyclohexyl analogues. The most promising compound of the present series, 3 , had equal to (one example) or lower MIC values than standard antibiotics and were bactericidal against Gram positive bacteria. While the standard antibiotics often had lower MIC values against Gram negative bacteria, 3, by contrast to the standards, was generally bactericidal offering potential as a novel therapeutic agent for the treatment of a wide range of bacterial infections. In summary, the new results reported herein coupled with recently discoveries of other gold compounds of other thiolates [64], sulfanylcarboxylates [65], and carbenes [66] indicates further research investigating the antibacterial activity of gold compounds is warranted.

\section{Acknowledgements}


The authors thank the Ministry of Higher Education (Malaysia) and the University of Malaya for funding this research through the High-Impact Research scheme (UM.C/HIR-MOHE/SC/12). The Department of Biomedical Science, Universiti Putra Malaysia, is thanked for access to the bioassay facilities. 


\section{References}

[1] R. Choudhury, S. Panda, D.V. Singh, Indian J. Med. Microbiol. 30 (2012) 384-390.

[2] O. Cars, A. Hedin, A. Heddini, Drug Resist. Updates 14 (2011) 68-69.

[3] C.-C. Lai, K. Lee, Y. Xiao, N. Ahmad, B. Veeraraghavan, V. Thamlikitkul, P.A. Tambyah, R. Nelwan, A.M. Shibl, J.-J. Wu, W.-H. Seto, P.-R. Hsueh, J. Global Antimicrobial Resist. 2 (2014) 141-147.

[4] Antimicrobial resistance: global report on surveillance. World Health Organization, 2014.

[5] N. Woodford, M.J. Ellington, Clin. Microbiol. Infection 13 (2007) 5-18.

[6] E. Zankari, H. Hasman, S. Cosentino, M. Vestergaard, S. Rasmussen, O. Lund, F.M. Aarestrup, M.V. Larsen, J. Antimicrob Chemother. 67 (2012) 2640-2644.

[7] L. Silver, Clin. Microbiol. Rev. 24 (2011) 71-109.

[8] H.W. Boucher, G.H. Talbot, J.S. Bradley, J.E. Edwards, D. Gilbert, L.B. Rice, M. Scheld, B. Spellberg, J. Bartlett, Clin. Infect Dis. 48 (2009) 1-12.

[9] I.N. Okeke, R. Laxminarayan, Z.A. Bhutta, A.G. Duse, P. Jenkins, T.F. O'Brien, A. Pablos-Mendez, K.P. Klugman, Lancet Infectious Dis. 5 (2005) 481-493.

[10] L. Freire-Moran, B. Aronsson, C. Manz, I.C. Gyssens, A.D. So, D.L. Monnet, O. Cars, Drug Resist. Updates 14 (2011) 118-124.

[11] G. Alvan, C. Edlund, A. Heddini, Drug Resist. Updates 14 (2011) 70-76.

[12] R. Wise, J. Antimicrob Chemother. 66 (2011) 1939-1940.

[13] M. Gielen and E.R.T. Tiekink (Eds.), Metallotherapeutic Drugs and Metal-Based Diagnostic Agents: The Use of Metals in Medicine, John Wiley \& Sons Ltd, Chichester, 2005.

[14] W.F. Kean, I.R.L. Kean, Inflammopharmacology 16 (2008) 112-125. 
[15] E.A. Pacheco, E.R.T. Tiekink, M.W. Whitehouse, in: C. Corti, R. Holliday (Eds.), Gold: Science and Applications, CRC Press, Boca Raton, 2009, pp. 217-230.

[16] I. Ott, Coord. Chem. Rev. 253 (2009) 1670-1681.

[17] S.J. Berners-Price, A. Filipovska, Metallomics 3 (2011) 863-873.

[18] C.-M. Che, R.W.-Y. Sun, Chem. Commun. 47 (2011) 9554-9560.

[19] B. Bertrand, A. Casini, Dalton Trans 43 (2014) 4209-4219.

[20] T. Zou, C.T. Lum, C.-N. Lok, J.-J. Zhang, C.-M. Che, Chem. Soc. Rev. 44 (2015) 87868801.

[21] B.Đ. Glišić, M.I. Djuran, Dalton Trans 43 (2014) 950-5969.

[22] Z.Y. Pessetto, S.J. Weir, G. Sethi, M.A. Broward, A.K. Godwin, Mol. Cancer Ther. 12 (2013) 1299-1309.

[23] C. Roder, M.J. Thomson, Drugs R. D. 15 (2015) 13-20.

[24] M.I. Casetta, T. Marzo, S. Fallani, A. Novelli, L. Messori, Biometals 27 (2014) 787791.

[25] D.T. Hill, B.M. Sutton, Cryst. Struct. Commun. 9 (1980) 679-686.

[26] E.R.T. Tiekink, Crit. Rev. Hematol. Oncol. 42 (2002) 225-245.

[27] E.R.T. Tiekink, Gold Bull. 36 (2003) 117-124.

[28] E.R.T. Tiekink, Inflammopharmacology, 16 (2008) 138-142.

[29] E.R.T. Tiekink, P.D. Cookson, B.M. Linahan, L.K. Webster, Metal-Based Drugs 1 (1994) 299-304.

[30] L.K. Webster, S. Rainone, E. Horn, E.R.T. Tiekink, Metal-Based Drugs 3 (1996) 63-66.

[31] D. Crump, G. Siasios and E.R.T. Tiekink, Metal-Based Drugs 6 (1999) 361-368. 
[32] D. de Vos, P. Clements, S.M. Pyke, D.R. Smyth and E.R.T. Tiekink, Metal-Based Drugs 6 (1999) 31-40.

[33] D. de Vos, D.R. Smyth and E.R.T. Tiekink, Metal-Based Drugs 8 (2001) 303-306.

[34] B.R. Vincent, D.J. Clarke, D.R. Smyth, D. de Vos and E.R.T. Tiekink, Metal-Based Drugs 8 (2001) 79-84.

[35] D. de Vos, S.Y. Ho and E.R.T. Tiekink, Bioinorg. Chem. Applns 2 (2004) 141-154.

[36] G. Hogarth, Mini-Rev. Med. Chem. 12 (2012) 1202-1215.

[37] L. Ronconi, L. Giovagnini, C. Marzano, F. Bettìo, R. Graziani, G. Pilloni, D. Fregona, Inorg. Chem. 44 (2005) 1867-1881.

[38] V. Gandina, A.P. Fernandes, M.P. Rigobello, B. Dani, F. Sorrentino, F. Tisato, M. Björnstedt, A. Bindolie, A. Sturaro, R. Rella, C. Marzano, Biochem. Pharm. 79 (2010) 90-101.

[39] N.S. Jamaludin, Z.-J. Goh, Y.K. Cheah, K.-P. Ang, J.H. Sim, C.H. Khoo, Z.A. Fairuz, S.N.A. Halim, S.W. Ng, H.-L. Seng, E.R.T. Tiekink, Eur. J. Med. Chem. 67 (2013) 127141.

[40] F.K. Keter, I.A. Guzei, M. Nell, W.E. van Zyl, J. Darkwa, Inorg. Chem. 53 (2014) 2058-2067.

[41] M. Altaf, M. Monim-ul-Mehboob, A.A.A. Seliman, M. Sohail, M.I.M. Wazeer, A.A. Isab, L. Li, V. Dhuna, G. Bhatia, K. Dhuna, Eur. J. Med. Chem. 95 (2015) 464-472.

[42] J.-H. Sim, N.S. Jamaludin, C.-H. Khoo, Y.-K. Cheah, S.N.B.A. Halim, H.-L. Seng, E.R.T. Tiekink, Gold Bull. 47 (2014) 225-236.

[43] C.I. Yeo, J.-H. Sim, C.-H. Khoo, Z.-J. Goh, K.-P. Ang, Y.-K. Cheah, Z.A. Fairuz, S.N.B.A. Halim, S.W. Ng, H.-L. Seng, E.R.T. Tiekink, Gold Bull. 46 (2013) 145-152. 
[44] N.S. Jamaludin, S.N.A. Halim, C.-H. Khoo, B.-J. Chen, T.-H. See, J.-H. Sim, Y.-K. Cheah, H.-L. Seng, E. R. T. Tiekink, Z. Kristallogr. 231 (2016) 341-349.

[45] R.A. Howie, G.M. de Lima, D.C. Menezes, J.L. Wardell, S.M.S.V. Wardell, D.J. Young, E.R.T. Tiekink, CrystEngComm 10 (2008) 1626-1637.

[46] P.J. Petersen, C.H. Jones, P.A. Bradford, 59 (2007) 347-349.

[47] S.Y. Ho, Tiekink, E.R.T. Z. Kristallogr. New Cryst. Struct. 220 (2005) 342-344.

[48] D.H.A. Ishak, K.K. Ooi, K.P. Ang, A.Md. Akim, Y.-K. Cheah, N. Nordin, S.N.B.A. Halim, H.-L. Seng, E.R.T. Tiekink, J. Inorg. Biochem. 130 (2014) 38-51.

[49] Y.S. Tan, K.K. Ooi, K.P. Ang, A.Md Akim, Y.-K. Cheah, S.N.A. Halim, H.-L. Seng, E.R.T. Tiekink, J. Inorg. Biochem. 150 (2015) 48-62.

[50] J.G. Wijnhoven, W.P. Bosman, P.T. Beurskens, J. Cryst. Mol. Struct. 2 (1972) 7-15.

[51] S.Y. Ho, Tiekink, E.R.T. Tiekink, Acta Crystallogr. E57 (2001) m603-m604.

[52] S.Y. Ho, Tiekink, E.R.T. Tiekink, Acta Crystallogr. E58 (2002) m86-m87.

[53] S.Y. Ho, Tiekink, E.R.T. Z. Kristallogr. New Cryst. Struct. 217 (2002) 359-360.

[54] S.Y. Ho, Tiekink, E.R.T. Z. Kristallogr. New Cryst. Struct. 219 (2004) 73-74.

[55] E. Vergara, S. Miranda, F. Mohr, E. Cerrada, E.R.T. Tiekink, P. Romero, A. Mendia, M. Laguna, Eur. J. Inorg. Chem. (2007) 2926-2933.

[56] S. Naeem, S.A. Serapian, A. Toscani, A.J.P. White, G. Hogarth, J.D.E.T. Wilton-Ely, Inorg. Chem. 53 (2014) 2404-2416.

[57] H. Nikaido, Semin. Cell Dev. Biol. 12 (2001) 215-223.

[58] G.J. Kaur, D.S. Arora, BMC Comp. Altern. Med. 9 (2009) 30-39. 
[59] R.W. Finberg, R.C. Moellering, F.P. Tally, W.A. Craig, G.A. Pankey, E.P. Dellinger, M.A. West, M. Joshi, P.K. Linden, K.V. Rolston, J.C. Rotschafer, M.J. Rybak, M.J. Clin. Infect. Dis. 39 (2004) 1314-1320.

[60] G.A. Pankey, L.D. Sabath, Clin. Infect. Dis. 38 (2004) 864-870.

[61] M.E. Levison, Infect. Dis. Clin. N. Am. 18 (2004) 451-465.

[62] M. Mueller, A. de la Pena, H. Derendorf, Antimicrob. Agents Chemother. 48 (2004) 369377.

[63] V.H. Tam, A.N. Schilling, M. Nikolaou, J. Antimicrob. Chemother. 55 (2005) 699-706.

[64] Y. Hokai, B. Jurkowicz, J. Fernández-Gallardo, N. Zakirkhodjaev, M. Sanaú, T.R. Muth, M. Contel, J. Inorg. Bichem. 138 (2014) 81-88.

[65] E. Barreiro, J.S. Casas, M.D. Couce, A. Sánchez, A. Sánchez-Gonzalez, J. Sordo, E.M. Vázquez-López, J. Inorg. Bichem. 138 (2014) 89-98.

[66] G.A. Fernández, M.S. Vela Gurovic, N.L. Olivera, A.B. Chopa, G.F. Silbestri, J. Inorg. Bichem. 138 (2014) 81-88. 
Table 1

Anti-bacterial activity measured by zone of inhibition $(\mathrm{mm})$ of dithiocarbamate anions, $\mathbf{1 - 4}$, and standard anti-biotics.

\begin{tabular}{|c|c|c|c|c|c|c|c|c|c|}
\hline Microorganism & $-\mathrm{S}_{2} \mathrm{CNR}_{2}{ }_{2}$ & 1 & 2 & $-\mathrm{S}_{2} \mathrm{CNR}_{2}^{2}$ & 3 & $-\mathrm{S}_{2} \mathrm{CNR}^{3}$ & 4 & $\begin{array}{l}\text { Tetracycline } \\
(30 \mu \mathrm{g} / \text { disc })\end{array}$ & $\begin{array}{c}\text { Chloramphenicol } \\
\qquad(30 \mu \mathrm{g} / \mathrm{disc})\end{array}$ \\
\hline B. cereus ATCC 10876 & - & 8 & 7 & 7 & 22 & 12 & 24 & 17 & ND \\
\hline B. subtilis ATCC 6633 & - & 10 & 8 & 11 & 27 & 17 & 29 & 31 & ND \\
\hline E. faecium ATCC 19434 & - & 8 & 8 & - & 20 & - & 21 & ND & 22 \\
\hline L. monocytogenes ATCC 19117 & - & 9 & 8 & - & 24 & 13 & 24 & 27 & ND \\
\hline S. aureus (MRSA) ATCC 43300 & - & 10 & 8 & - & 27 & 14 & 28 & ND & 20 \\
\hline \multicolumn{10}{|l|}{ Gram-negative bacteria } \\
\hline A. baumannii ATCC 19606 & - & - & - & - & 14 & - & 12 & 20 & ND \\
\hline A. hydrophilla ATCC35654 & - & - & - & - & 14 & 10 & 12 & 27 & ND \\
\hline
\end{tabular}




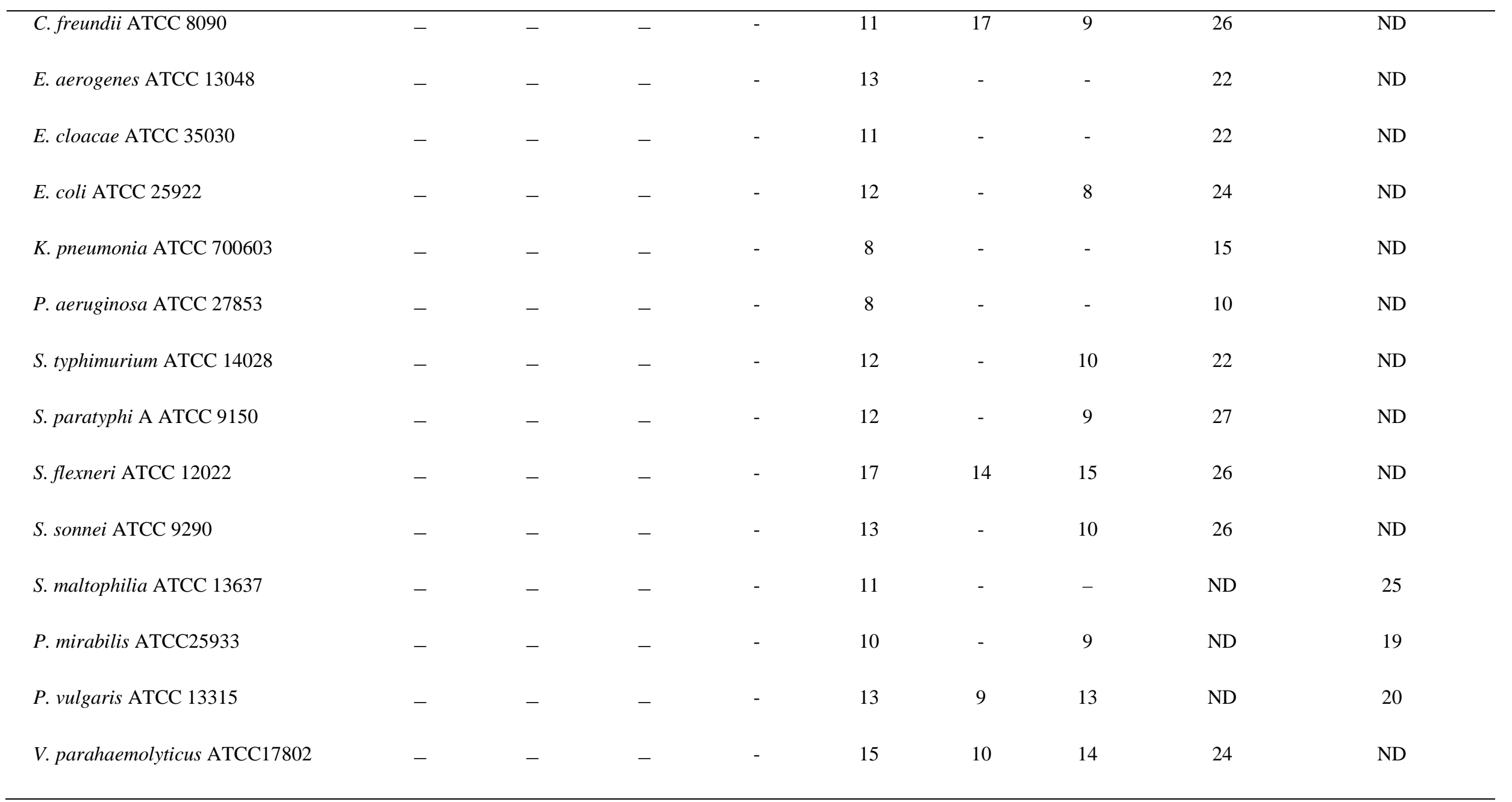

${ }^{a}$ The diameter of inhibition zones in millimetres were measured around the disc after $24 \mathrm{~h}$ incubation; -, no zone of inhibition; $\mathrm{ND}$, not determined. ${ }^{\mathrm{b}} \mathrm{R}^{1}=\mathrm{CH}_{2} \mathrm{CH}_{2} \mathrm{OH}, \mathrm{R}^{2}=$ ethyl, and $\mathrm{R}^{3}$ 


\section{Table 2}

MIC (in microgram per milliliter) and MBC (in microgram per milliliter) dithiocarbamate anions, $\mathbf{1 - 4}$, and standard anti-biotics against susceptible Gram-positive and Gram-negative bacteria. ${ }^{a}$

\begin{tabular}{|c|c|c|c|c|c|c|c|c|c|c|c|c|c|c|}
\hline \multirow[t]{2}{*}{ Microorganism } & \multicolumn{2}{|c|}{1} & \multicolumn{2}{|c|}{2} & \multicolumn{2}{|c|}{$-\mathrm{S}_{2} \mathrm{CNR}_{2}{ }_{2}$} & \multicolumn{2}{|c|}{3} & \multicolumn{2}{|c|}{$-\mathrm{S}_{2} \mathrm{CNR}^{3}$} & \multicolumn{2}{|c|}{4} & \multicolumn{2}{|c|}{$\begin{array}{c}\text { Standard anti- } \\
\text { biotics }\end{array}$} \\
\hline & MIC & $\begin{array}{l}\mathrm{MBC} / \\
\mathrm{MIC}\end{array}$ & MIC & $\begin{array}{l}\mathrm{MBC} / \\
\mathrm{MIC}\end{array}$ & MIC & $\begin{array}{l}\mathrm{MBC} / \\
\mathrm{MIC}\end{array}$ & MIC & $\begin{array}{l}\mathrm{MBC} / \\
\mathrm{MIC}\end{array}$ & MIC & $\begin{array}{l}\mathrm{MBC} / \\
\mathrm{MIC}\end{array}$ & MIC & $\begin{array}{l}\mathrm{MBC} / \\
\mathrm{MIC}\end{array}$ & MIC & $\begin{array}{l}\mathrm{MBC} / \\
\mathrm{MIC}\end{array}$ \\
\hline \multicolumn{15}{|l|}{ Gram-positive bacteria } \\
\hline B. cereus АTCC 10876 & 0.39 & 1 & 1.56 & 2 & 100.00 & ND & 0.10 & 1 & 6.25 & $>16$ & 0.10 & $>1024$ & $6.25^{\mathrm{c}}$ & 1 \\
\hline B. subtilis ATCC 6633 & 0.78 & 1 & 25.00 & 1 & 100.00 & ND & 0.10 & 1 & 12.50 & $>8$ & 0.05 & $>2048$ & $0.10^{\mathrm{c}}$ & 1 \\
\hline E. faecalis АТСС 29212 & 6.25 & 1 & 12.50 & 1 & - & - & 0.39 & 1 & 25.00 & 1 & 0.20 & $>512$ & $12.50^{\mathrm{c}}$ & 1 \\
\hline E. faecium АTCC 19434 & 3.13 & 16 & 6.25 & 16 & - & - & 0.39 & 8 & - & - & 0.39 & $>256$ & $12.50^{\mathrm{d}}$ & ND \\
\hline L. monocytogenes ATCC 19117 & 1.56 & 1 & 1.56 & 1 & - & - & 0.20 & 1 & 12.50 & $>8$ & 020 & 1 & $12.50^{\mathrm{c}}$ & 1 \\
\hline S. aureus (MRSA) ATCC 43300 & 1.56 & 1 & 6.25 & 2 & - & - & 0.10 & 1 & 25.00 & ND & 0.10 & 512 & $12.50^{\mathrm{d}}$ & 1 \\
\hline S. aureus ATCC 25923 & 1.56 & 1 & 50.00 & 1 & - & - & 0.10 & 1 & 12.50 & 1 & 0.10 & 1 & $12.50^{\mathrm{d}}$ & 1 \\
\hline S. saprophyticus АТСС 15305 & 1.56 & 1 & 3.13 & 8 & - & - & 0.10 & 2 & 12.50 & $>8$ & 0.10 & 4 & $0.39^{\mathrm{c}}$ & ND \\
\hline \multicolumn{15}{|l|}{ Gram-negative bacteria } \\
\hline A. baumannii АТСC 19606 & - & - & - & - & - & - & 1.56 & 1 & - & - & 1.56 & $>64$ & $0.39^{c}$ & 32 \\
\hline A. hydrophilla АТСC 35654 & - & - & - & - & - & - & 0.78 & 1 & 50.00 & ND & 3.13 & 2 & $0.39^{c}$ & 1 \\
\hline C. freundii АТСС 8090 & - & - & - & - & - & - & 6.25 & 4 & 3.125 & $>32$ & 25.00 & $>4$ & $0.78^{\mathrm{c}}$ & 32 \\
\hline E. aerogenes АТСC 13048 & - & - & - & - & - & - & 1.56 & 2 & - & - & - & - & $1.56^{\mathrm{c}}$ & 32 \\
\hline E. cloacae АТСС 35030 & - & - & - & - & - & - & 6.25 & 2 & - & - & - & - & $1.56^{\mathrm{c}}$ & ND \\
\hline E. coli $\mathrm{ATCC} 25922$ & - & - & - & - & - & - & 3.13 & 2 & - & - & 12.50 & 8 & $0.39^{c}$ & ND \\
\hline K. pneumonia АTCC 700603 & - & - & - & - & - & - & 6.25 & 8 & - & - & - & - & $12.50^{\mathrm{c}}$ & ND \\
\hline
\end{tabular}




\begin{tabular}{|c|c|c|c|c|c|c|c|c|c|c|c|c|c|c|}
\hline P. aeruginosa АТСC 27853 & - & - & - & - & - & - & 12.50 & $>8$ & - & - & - & - & $6.25^{\mathrm{c}}$ & ND \\
\hline S. typhimurium АТCC 14028 & - & - & - & - & - & - & 3.13 & 2 & - & - & 6.25 & $>16$ & $1.56^{\mathrm{c}}$ & 32 \\
\hline S. paratyphi А АтсC 9150 & - & - & - & - & - & - & 1.56 & 1 & - & - & 12.50 & 8 & $1.56^{\mathrm{c}}$ & 32 \\
\hline S. flexneri АТСС 12022 & - & - & - & - & - & - & 1.56 & 2 & 12.50 & $>8$ & 3.13 & 4 & $0.78^{\mathrm{c}}$ & 32 \\
\hline S. sonnei АТСС 9290 & - & - & - & - & - & - & 3.13 & 2 & - & - & 1.56 & 2 & $0.78^{\mathrm{c}}$ & 32 \\
\hline S. maltophilia АТСС 13637 & - & - & - & - & - & - & 1.56 & 8 & - & - & - & - & $3.13^{\mathrm{d}}$ & ND \\
\hline P. mirabilis АТСC25933 & - & - & - & - & - & - & 6.25 & 2 & - & - & - & - & $12.50^{\mathrm{d}}$ & 8 \\
\hline P. vulgaris АТСС 13315 & - & - & - & - & - & - & 3.13 & 2 & 50.00 & ND & 3.13 & 4 & $12.50^{\mathrm{d}}$ & 4 \\
\hline V. parahaemolyticus ATCC 17802 & - & - & - & - & - & - & 0.39 & 2 & 25.00 & ND & 0.39 & 1 & $0.10^{c}$ & 1 \\
\hline
\end{tabular}

${ }^{\text {a }} M I C$ minimum inhibitory concentration $(\mu \mathrm{g} / \mathrm{ml}), M B C$ minimum bactericidal concentration $(\mu \mathrm{g} / \mathrm{ml}), M B C / M I C$ ratio for bacteriostatic or bactericidal activity, - not applicable, $N D$, not determined as the bacterium had grown across all tested dilutions $(M B C>2000 \mu \mathrm{g} / \mathrm{ml})$, MBC/MIC > 4 showed bacteriostatic properties. ${ }^{\mathrm{b}} \mathrm{R}^{1}=\mathrm{CH}_{2} \mathrm{CH}_{2} \mathrm{OH}, \mathrm{R}^{2}=$ ethyl, and $\mathrm{R}^{3}=\left(\mathrm{CH}_{2}\right)_{4} .{ }^{\mathrm{c}}$ tetracycline. ${ }^{\mathrm{d}}$ chloramphenicol. 


\section{Table 3}

Summary of in vitro time-kill assay of $\mathbf{1}$ and $\mathbf{2}$ against susceptible pathogen strains.

\begin{tabular}{|c|c|c|c|c|c|c|c|c|c|c|c|c|c|c|c|c|c|c|c|}
\hline \multirow{3}{*}{ Microorganism } & \multirow{3}{*}{ Compound } & \multicolumn{18}{|c|}{$\Delta \log _{10} \mathrm{cfu} / \mathrm{ml}^{\mathrm{a}}$} \\
\hline & & \multicolumn{6}{|c|}{$1 / 2 \times \mathrm{MIC}$} & \multicolumn{6}{|c|}{ MIC } & \multicolumn{6}{|c|}{$2 \times \mathrm{MIC}$} \\
\hline & & $1 \mathrm{~h}$ & $2 \mathrm{~h}$ & $3 \mathrm{~h}$ & $4 \mathrm{~h}$ & $8 \mathrm{~h}$ & $24 \mathrm{~h}$ & $1 \mathrm{~h}$ & $2 \mathrm{~h}$ & $3 \mathrm{~h}$ & $4 \mathrm{~h}$ & $8 \mathrm{~h}$ & $24 \mathrm{~h}$ & $1 \mathrm{~h}$ & $2 \mathrm{~h}$ & $3 \mathrm{~h}$ & $4 \mathrm{~h}$ & $8 \mathrm{~h}$ & $24 h$ \\
\hline \multirow[t]{2}{*}{ B. cereus ATCC 10876} & 1 & +0.7 & +1.5 & +2.8 & +3.1 & +3.9 & +4.9 & -5.1 & -1.6 & -1.1 & $\begin{array}{l}-0.9 \\
\end{array}$ & +3.1 & +4.3 & -5.1 & $\begin{array}{c}-5.1 \\
\end{array}$ & $\begin{array}{c}-5.1 \\
\end{array}$ & -2.5 & +1.6 & +4.0 \\
\hline & 2 & +0.1 & +0.7 & +1.8 & +2.8 & +3.5 & +3.0 & -2.3 & -2.0 & -1.3 & -0.1 & +2.9 & +2.8 & -5.1 & -5.1 & -5.1 & -5.1 & -5.1 & +2.8 \\
\hline \multirow[t]{2}{*}{ B. subtilis АТсС 6633} & 1 & -0.3 & -0.1 & +0.5 & +1.1 & +3.1 & +3.2 & -2.0 & -3.3 & -5.1 & -2.2 & +0.9 & +2.9 & -5.1 & -5.1 & -5.1 & -2.6 & +0.6 & +2.9 \\
\hline & 2 & -5.1 & -5.1 & -5.1 & -5.1 & -5.1 & +0.3 & -5.1 & -5.1 & -5.1 & -5.1 & -5.1 & -0.2 & -5.1 & -5.1 & -5.1 & -5.1 & -5.1 & -1.2 \\
\hline \multirow[t]{2}{*}{ E. faecalis АTCC 29212} & 1 & +0.1 & +0.1 & +0.2 & 0.0 & -0.4 & +5.9 & 0.0 & -0.1 & -0.2 & -0.4 & -1.9 & +1.4 & 0.0 & 0.4 & -0.5 & -1.6 & -3.1 & -2.6 \\
\hline & 2 & -0.1 & -2.3 & -2.0 & -1.8 & -1.3 & +6.0 & -0.3 & -3.3 & -5.7 & -5.7 & -5.7 & -5.7 & -1.8 & -5.7 & -5.7 & -5.7 & -5.7 & -5.7 \\
\hline \multirow[t]{2}{*}{ E. faecium АТСС 19434} & 1 & 0.0 & +0.6 & +1.7 & +3.0 & +5.8 & +6.0 & -0.2 & +0.4 & +0.7 & +2.5 & +5.7 & +5.9 & -0.2 & +0.2 & +0.2 & +0.3 & +0.9 & +5.9 \\
\hline & 2 & +0.2 & +0.8 & +0.7 & +4.3 & +3.2 & +3.9 & -0.2 & 0.0 & -0.1 & +0.5 & +1.3 & +2.9 & -0.1 & -0.2 & 0.1 & +0.2 & +2.8 & +2.9 \\
\hline \multirow[t]{2}{*}{ L. monocytogenes ATCC 19117} & 1 & +0.1 & +0.1 & +0.9 & +1.8 & +4.8 & +5.2 & -0.1 & -0.1 & -0.1 & -0.4 & +4.1 & +5.1 & -0.2 & -0.2 & -0.1 & -0.3 & -0.3 & +5.1 \\
\hline & 2 & -0.2 & -0.1 & +0.5 & +0.8 & +2.0 & +5.0 & -0.1 & -0.1 & +0.1 & +0.5 & +1.9 & +4.9 & -0.1 & -0.2 & -0.3 & -0.2 & -0.8 & +4.9 \\
\hline \multirow[t]{2}{*}{ S. aureus (MRSA) АТСС 43300} & 1 & +0.4 & +0.2 & +0.1 & +0.1 & -0.3 & +6.2 & -0.4 & -0.6 & -1.0 & -1.2 & -2.7 & +2.9 & -0.4 & -1.0 & -1.5 & -2.4 & -5.4 & -5.4 \\
\hline & 2 & -5.4 & -5.4 & -5.4 & -5.4 & -5.4 & -0.6 & -5.4 & -5.4 & -5.4 & -5.4 & -5.4 & -5.4 & -5.4 & -5.4 & -5.4 & -5.4 & -5.4 & -5.4 \\
\hline \multirow[t]{2}{*}{ S. aureus АTCC 25923} & 1 & +0.2 & +0.5 & +1.5 & +1.7 & +6.5 & +6.9 & -0.2 & +0.1 & +0.1 & -0.2 & -0.4 & +3.6 & -0.3 & -0.2 & -0.3 & -0.4 & -1.5 & +1.6 \\
\hline & 2 & -0.1 & +0.2 & +0.5 & +1.2 & +3.3 & +5.8 & -0.2 & -0.2 & -0.3 & -0.5 & -0.5 & +5.7 & -0.2 & -0.2 & -0.4 & -0.8 & -4.6 & +0.6 \\
\hline \multirow[t]{2}{*}{ S. saprophyticus ATCC 15305} & 1 & +0.2 & +0.3 & +1.0 & +1.1 & +6.5 & +6.6 & -0.1 & -0.1 & -0.3 & -0.3 & -0.8 & +6.6 & -0.4 & -0.6 & -0.6 & -0.6 & +0.3 & +6.4 \\
\hline & 2 & +0.2 & +0.4 & +1.1 & +1.4 & +5.9 & +6.7 & -0.0 & -0.3 & +0.1 & +0.1 & +1.8 & +6.6 & -4.9 & -4.9 & -4.9 & -4.9 & -4.9 & +6.5 \\
\hline
\end{tabular}


${ }^{a}$ Relative to $\log _{10} \mathrm{cfu} / \mathrm{ml}$ of initial inoculum (a negative value indicates a reduction of bacterial cell number, and a positive value indicates an increase of bacterial cell number). Values shown are the means of triplicate determinations from each experiment. 


\section{Table 4}

Summary of in vitro time-kill assay of $\mathbf{3}$ and $\mathbf{4}$ against susceptible pathogen strains.

\begin{tabular}{|c|c|c|c|c|c|c|c|c|c|c|c|c|c|c|c|c|c|c|c|}
\hline \multirow{3}{*}{ Microorganism } & \multirow{3}{*}{ Compound } & \multicolumn{18}{|c|}{$\Delta \log _{10} \mathrm{cfu} / \mathrm{ml}^{\mathrm{a}}$} \\
\hline & & \multicolumn{6}{|c|}{$1 / 2 \times$ MIC } & \multicolumn{6}{|c|}{ MIC } & \multicolumn{6}{|c|}{$2 \times \mathrm{MIC}$} \\
\hline & & $1 \mathrm{~h}$ & $2 \mathrm{~h}$ & $3 \mathrm{~h}$ & $4 \mathrm{~h}$ & $8 \mathrm{~h}$ & $24 \mathrm{~h}$ & $1 \mathrm{~h}$ & $2 \mathrm{~h}$ & $3 \mathrm{~h}$ & $4 \mathrm{~h}$ & $8 \mathrm{~h}$ & $24 \mathrm{~h}$ & $1 \mathrm{~h}$ & $2 \mathrm{~h}$ & $3 \mathrm{~h}$ & $4 \mathrm{~h}$ & $8 \mathrm{~h}$ & $24 \mathrm{~h}$ \\
\hline \multicolumn{20}{|l|}{ Gram-positive bacteria } \\
\hline \multirow[t]{2}{*}{ B. cereus АTCC 10876} & 3 & +0.1 & -0.1 & -0.1 & -0.1 & -0.2 & +3.0 & +0.1 & -0.2 & -0.3 & -0.4 & -0.9 & -2.2 & -0.6 & -0.4 & -1.1 & -1.3 & -5.2 & -5.2 \\
\hline & 4 & -0.1 & +0.1 & +0.1 & +0.1 & 0.0 & +2.8 & -0.3 & -0.3 & -0.3 & -0.2 & -0.3 & -1.7 & -0.7 & -0.2 & -0.2 & -0.2 & -0.5 & -2.2 \\
\hline \multirow[t]{2}{*}{ B. subtilis АТСС 6633} & 3 & -1.5 & -5.1 & -5.1 & -5.1 & -5.1 & -5.1 & -5.1 & -5.1 & -5.1 & -5.1 & -5.1 & -5.1 & -5.1 & -5.1 & -5.1 & -5.1 & -5.1 & -5.1 \\
\hline & 4 & +0.1 & -0.1 & -0.3 & -0.1 & +2.7 & +3.1 & -0.1 & -1.4 & -0.3 & -0.3 & -0.8 & +2.8 & -0.1 & -0.2 & -0.4 & -0.4 & -1.0 & -1.6 \\
\hline \multirow{2}{*}{ E. faecalis АТСC 29212} & 3 & 0.0 & +0.1 & 0.0 & 0.0 & 0.0 & -1.9 & 0.0 & +0.1 & 0.0 & 0.0 & -0.1 & -5.8 & -0.1 & -0.2 & -0.1 & -0.1 & -0.1 & -5.8 \\
\hline & 4 & +0.2 & +0.1 & -0.1 & -0.1 & -0.1 & +0.4 & +0.1 & 0.0 & -0.1 & -0.2 & -0.2 & 0.0 & 0.0 & -0.1 & -0.2 & -0.2 & -0.3 & -0.1 \\
\hline \multirow[t]{2}{*}{ E. faecium ATCC 19434} & 3 & -0.1 & 0.0 & -0.1 & -0.1 & +0.2 & +1.2 & 0.0 & 0.0 & 0.0 & -0.2 & 0.0 & +0.3 & -0.3 & +0.1 & -0.1 & -0.2 & +0.2 & -0.2 \\
\hline & 4 & 0.0 & -0.1 & 0.0 & +0.3 & +0.3 & 0.0 & -0.1 & -0.1 & 0.0 & +0.1 & -0.1 & 0.0 & -0.1 & -0.1 & -0.1 & 0.0 & +0.1 & 0.0 \\
\hline \multirow[t]{2}{*}{ L. monocytogenes ATCC 19117} & 3 & -0.1 & +0.2 & +0.1 & -0.1 & -0.4 & -1.5 & -0.1 & 0.0 & -0.1 & -0.1 & -0.4 & -6.4 & -0.1 & -0.1 & -0.1 & -0.3 & -0.8 & -6.4 \\
\hline & 4 & -0.1 & +0.1 & -0.1 & +0.1 & -0.3 & +0.8 & -0.1 & -0.2 & -0.1 & -0.1 & -0.4 & -2.7 & 0.0 & -0.4 & -0.1 & -0.1 & -1.2 & -2.7 \\
\hline \multirow[t]{2}{*}{ S. aureus (MRSA) ATCC 43300} & 3 & 0.0 & 0.0 & +0.1 & -0.1 & -0.2 & -1.0 & -0.1 & -0.4 & -0.5 & -0.7 & -1.9 & -5.7 & -0.3 & -0.8 & -1.8 & -2.1 & -4.1 & -5.7 \\
\hline & 4 & +0.2 & +0.1 & +0.2 & +0.1 & +0.1 & +5.8 & +0.1 & 0.0 & +0.1 & +0.1 & 0.0 & -0.3 & -0.2 & 0.0 & 0.0 & 0.0 & -0.4 & -0.8 \\
\hline \multirow[t]{2}{*}{ S. aureus ATCC 25923} & 3 & +0.1 & 0.0 & -0.1 & 0.0 & -0.1 & -0.5 & +0.1 & 0.0 & -0.1 & -0.1 & -0.9 & -5.2 & 0.0 & -0.4 & -0.4 & -1.2 & -5.2 & -5.2 \\
\hline & 4 & 0.0 & -0.1 & 0.0 & 0.0 & 0.0 & +0.5 & 0.0 & 0.0 & 0.0 & -0.1 & 0.0 & +0.3 & 0.0 & -0.1 & -0.2 & -0.8 & -2.0 & -5.2 \\
\hline \multirow[t]{2}{*}{ S. saprophyticus ATCC 15305} & 3 & 0.0 & -0.8 & -2.1 & -5.0 & -5.0 & -5.0 & -0.7 & -5.0 & -5.0 & -5.0 & -5.0 & -5.0 & -5.0 & -5.0 & -5.0 & -5.0 & -5.0 & -5.0 \\
\hline & 4 & +0.3 & +0.4 & +0.2 & +0.2 & +0.4 & +3.6 & -0.1 & -0.1 & 0.0 & 0.0 & -0.6 & +1.2 & -0.1 & -0.4 & -0.8 & -1.8 & -5.0 & -5.0 \\
\hline
\end{tabular}




\begin{tabular}{|c|c|c|c|c|c|c|c|c|c|c|c|c|c|c|c|c|c|c|c|}
\hline \multicolumn{20}{|l|}{ Gram-negative bacteria } \\
\hline \multirow[t]{2}{*}{ A. baumannii АТСС 19606} & 3 & -0.1 & -0.1 & -0.2 & -0.3 & -1.7 & +0.4 & +0.1 & -0.3 & -0.4 & -1.0 & -6.0 & -6.0 & -0.2 & -0.6 & -1.3 & -6.0 & -6.0 & -6.0 \\
\hline & 4 & +0.4 & +1.3 & +5.2 & +5.2 & +5.5 & +5.6 & +0.1 & +1.1 & 3.9 & +5.0 & +4.9 & +5.6 & -0.1 & +0.7 & +2.7 & +3.9 & +4.5 & +5.5 \\
\hline \multirow[t]{2}{*}{ A. hydrophilla АТСС 35654} & 3 & +0.1 & +0.1 & +0.2 & +0.3 & +0.3 & +5.1 & -0.7 & -2.8 & -2.8 & -4.1 & -5.8 & -5.8 & -5.8 & -5.8 & -5.8 & -5.8 & -5.8 & -5.8 \\
\hline & 4 & 0.0 & 0.0 & 0.0 & +0.1 & +1.9 & +3.4 & 0.0 & -0.1 & -0.3 & -0.1 & -0.6 & +3.6 & -0.1 & -0.1 & -0.3 & -0.4 & -0.6 & 0.0 \\
\hline \multirow[t]{2}{*}{ C. freundii АТСС 8090} & 3 & +0.1 & +0.1 & +0.0 & -0.2 & -1.3 & -3.2 & -0.2 & -0.9 & -1.2 & -1.9 & -3.6 & -6.0 & -0.6 & -2.0 & -3.5 & -4.0 & -6.0 & -6.0 \\
\hline & 4 & +0.1 & +0.0 & +0.1 & +0.6 & +0.8 & +2.9 & 0.0 & 0.0 & +0.1 & +0.1 & +0.1 & +2.5 & -0.1 & 0.0 & 0.0 & 0.0 & 0.0 & -0.3 \\
\hline E. aerogenes АТСС 13048 & 3 & +0.1 & +0.2 & +0.2 & +0.3 & +4.9 & +9.7 & +0.1 & +0.1 & -0.1 & -0.5 & -1.2 & -3.3 & +0.1 & -0.7 & -0.9 & -1.6 & -5.8 & -5.8 \\
\hline E. cloacae атсс 35030 & 3 & 0.0 & -0.3 & -0.2 & -0.4 & -3.4 & -6.1 & -0.1 & -0.4 & -1.3 & -2.0 & -6.0 & -6.1 & -0.2 & -1.0 & -2.4 & -4.6 & -6.0 & -6.1 \\
\hline \multirow[t]{2}{*}{ E. coli АTCC 25922} & 3 & +0.2 & -0.4 & -1.5 & -1.7 & -3.1 & +3.4 & -0.3 & -1.3 & -3.5 & -5.4 & -5.4 & -5.4 & -0.5 & -2.5 & -5.4 & -5.4 & -5.4 & -5.4 \\
\hline & 4 & +0.3 & +0.3 & +0.7 & +0.9 & +0.2 & +3.2 & +0.1 & 0.0 & +0.3 & +0.3 & 0.0 & +3.0 & 0.0 & -0.2 & +0.1 & +0.1 & 0.0 & +0.1 \\
\hline K. pneumonia АТсC 700603 & 3 & +0.2 & +1.7 & +3.1 & +6.4 & +7.3 & +7.6 & 0.0 & -0.1 & -0.4 & -0.3 & -1.2 & +3.1 & +0.1 & -0.1 & -0.3 & -0.3 & -2.1 & -0.5 \\
\hline P. aeruginosa ATCC 27853 & 3 & 0.0 & +0.7 & +1.9 & +2.0 & +3.8 & +4.0 & -0.1 & +0.1 & +0.3 & +1.0 & +3.2 & +3.8 & -0.2 & 0.0 & +0.1 & +0.2 & +3.0 & +3.1 \\
\hline \multirow[t]{2}{*}{ S. typhimurium АTCC 14028} & 3 & 0.0 & +0.1 & -0.2 & -0.1 & -2.1 & +1.5 & -0.1 & -0.3 & -0.4 & -1.0 & -3.2 & -5.9 & -0.1 & -0.4 & -1.0 & -1.5 & -5.9 & -5.9 \\
\hline & 4 & -0.2 & -0.2 & -0.2 & -0.3 & -0.3 & +2.9 & -0.2 & -0.3 & -0.2 & -0.3 & -0.7 & +2.4 & -0.1 & -0.2 & -0.2 & -0.3 & -0.8 & +0.7 \\
\hline \multirow[t]{2}{*}{ S. paratyphi A ATCC 9150} & 3 & +0.1 & +0.6 & +1.3 & +2.0 & +2.9 & +3.1 & +0.2 & -0.8 & -1.4 & -2.1 & -1.9 & +3.1 & -0.8 & -2.7 & -3.4 & -4.2 & -5.8 & -5.8 \\
\hline & 4 & -0.2 & -0.4 & -0.2 & -0.3 & -0.6 & -1.2 & -0.4 & -0.3 & -0.2 & -0.4 & -0.8 & -1.7 & -0.4 & -0.4 & -0.4 & -0.4 & -0.7 & -2.1 \\
\hline \multirow[t]{2}{*}{ S. flexneri АТСC 12022} & 3 & 0.0 & +0.1 & 0.0 & 0.0 & -0.2 & -2.9 & 0.0 & -0.2 & -0.3 & 0.0 & -0.4 & -5.9 & 0.0 & -0.1 & -0.3 & -0.1 & -1.1 & -5.9 \\
\hline & 4 & +0.3 & -0.1 & -0.1 & -0.4 & -0.7 & +2.7 & -0.1 & -0.1 & -0.4 & -0.4 & -0.9 & +2.4 & 0.0 & -0.1 & -0.4 & -0.7 & -0.9 & -5.9 \\
\hline \multirow[t]{2}{*}{ S. sonnei АТсС 9290} & 3 & 0.0 & +0.2 & 0.0 & -0.1 & -0.2 & -2.8 & 0.0 & -0.1 & 0.0 & -0.1 & -0.9 & -5.8 & +0.1 & -0.1 & -0.1 & -0.7 & -1.8 & -5.8 \\
\hline & 4 & -0.1 & 0.0 & -0.3 & -0.8 & -1.1 & -0.1 & -0.2 & -0.1 & -0.5 & -0.9 & -1.1 & -2.3 & -0.1 & -0.3 & -0.8 & -0.9 & -1.6 & -3.1 \\
\hline S. maltophilia АТсC 13637 & 3 & 0.0 & +0.5 & +0.8 & +0.8 & +3.7 & +5.0 & -0.1 & +0.1 & +0.1 & +0.3 & +1.1 & +3.2 & -0.2 & -0.1 & -0.3 & -0.3 & -1.0 & +2.2 \\
\hline P. mirabilis АТCC 25933 & 3 & 0.0 & -0.1 & -0.3 & -0.5 & -2.3 & +5.2 & -0.1 & -0.3 & -0.4 & -0.5 & -4.8 & -6.1 & -0.1 & -0.2 & -0.5 & -1.2 & -6.0 & -6.1 \\
\hline
\end{tabular}




\begin{tabular}{|c|c|c|c|c|c|c|c|c|c|c|c|c|c|c|c|c|c|c|c|}
\hline \multirow[t]{2}{*}{ P. vulgaris ATCC 13315} & 3 & -6.0 & -6.0 & -6.0 & -6.0 & -6.0 & -6.0 & -6.0 & -6.0 & -6.0 & -6.0 & -6.0 & $\begin{array}{l}-6.0 \\
\end{array}$ & -6.0 & -6.0 & -6.0 & -6.0 & -6.0 & -6.0 \\
\hline & 4 & -0.1 & -1.2 & -3.5 & -6.0 & -6.0 & -6.0 & -0.2 & -1.6 & -6.0 & -6.0 & -6.0 & -6.0 & -0.4 & -1.8 & -6.0 & -6.0 & -6.0 & -6.0 \\
\hline \multirow[t]{2}{*}{ V. parahaemolyticus ATCC 17802} & 3 & -2.0 & -5.6 & -5.6 & -5.6 & -5.6 & -5.6 & -5.6 & -5.6 & -5.6 & -5.6 & -5.6 & -5.6 & -5.6 & -5.6 & -5.6 & -5.6 & -5.6 & -5.6 \\
\hline & 4 & +0.2 & +0.2 & -0.5 & -0.5 & -0.7 & +2.6 & -0.2 & -0.4 & -0.4 & -0.5 & -1.1 & +2.2 & -0.6 & -1.7 & -2.7 & -3.7 & -5.6 & -5.6 \\
\hline
\end{tabular}

${ }^{\text {a }}$ Relative to $\log _{10} \mathrm{cfu} / \mathrm{ml}$ of initial inoculum (a negative value indicates a reduction of bacterial cell number, and a positive value indicates

an increase of bacterial cell numbers). Values shown are the means of triplicate determinations from each experiment. 


\section{Captions to Figures}

Fig. 1. Chemical diagrams of the investigated phosphanegold(I) dithiocarbamates.

Fig 2. Time kill curves of 1 against (a) B. cereus, (b) B. subtilis, (c) E. faecalis, (d) E. faecium, (e) L. monocytogenes, (f) S. aureus (MRSA), (g) S. aureus, and (h) S. saprophyticus. The bactericidal level is indicated by the dashed lines $-\boldsymbol{Z}$, negative control $\square, 1 / 2 \mathrm{MIC} \triangle$, MIC $\nabla$, and $2 \mathrm{x}$ MIC

Fig 3. Time kill curves of 2 against (a) B. cereus, (b) B. subtilis, (c) E. faecalis, (d) E. faecium, (e) L. monocytogenes, (f) S. aureus (MRSA), (g) S. aureus, and (h) S. saprophyticus. The bactericidal

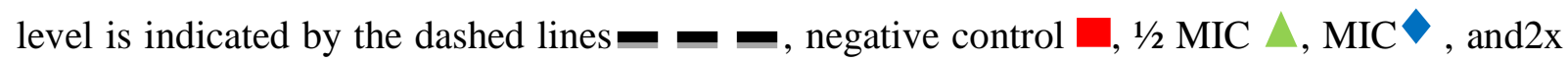
MIC

Fig 4. Time kill curves of $\mathbf{3}$ against (a) B. cereus, (b) B. subtilis, (c) E. faecalis, (d) E. faecium, (e) L. monocytogenes, (f) S. aureus (MRSA), (g) S. aureus, (h) S. saprophyticus, (i) A. baumannii, (j) A. hydrophila, (k) C. freundii, (1) E. aerogenes, (m) E. Cloacae, (n) E. coli, (o) K. pneumonia, (p) P. aeruginosa, (q) S. typhimurium, (r) S. paratyphi A (s) S. flexneri, (t) S. sonnei, (u) S. maltophilia, (v) P. mirabilis, (w) P. vulgaris, and (x) V. parahaemolyticus. The bactericidal level is indicated by the dashed lines $-\square$, negative control $\square, 1 / 2$ MIC $\triangle$, MIC $>$, and 2 x MIC

Fig 5. Time kill curves of $\mathbf{4}$ against (a) B. cereus, (b) B. subtilis, (c) E. faecalis, (d) E. faecium, (e) L. monocytogenes, (f) S. aureus (MRSA), (g) S. aureus, (h) S. saprophyticus, (i) A. baumannii, (j) 
A. hydrophila, (k) C. freundii, (1) E. coli, (m) S. typhimurium, (n) S. paratyphi A, (o) S. flexneri, (p) S. sonnei, (q) P. vulgaris, and (r) V. parahaemolyticus. The bactericidal level is indicated by the dashed lines $-\mathbf{-}$, negative control $\square, 1 / 2$ MIC $\triangle$, MIC $\diamond$, and $2 \times$ MIC $\bigcirc$. 


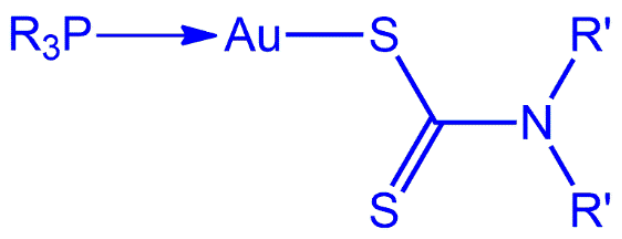

1: $\mathrm{R}=\mathrm{Ph}, \mathrm{R}^{\prime}=\mathrm{CH}_{2} \mathrm{CH}_{2} \mathrm{OH}$

2: $\mathrm{R}=\mathrm{Cy}, \mathrm{R}^{\prime}=\mathrm{CH}_{2} \mathrm{CH}_{2} \mathrm{OH}$

3: $\mathrm{R}=\mathrm{Et}, \mathrm{R}^{\prime}=\mathrm{CH}_{2} \mathrm{CH}_{3}$

4: $\mathrm{R}=\mathrm{Et}, \mathrm{R}^{\prime}=\mathrm{CH}_{2} \mathrm{CH}_{2}$

Figure 1. 

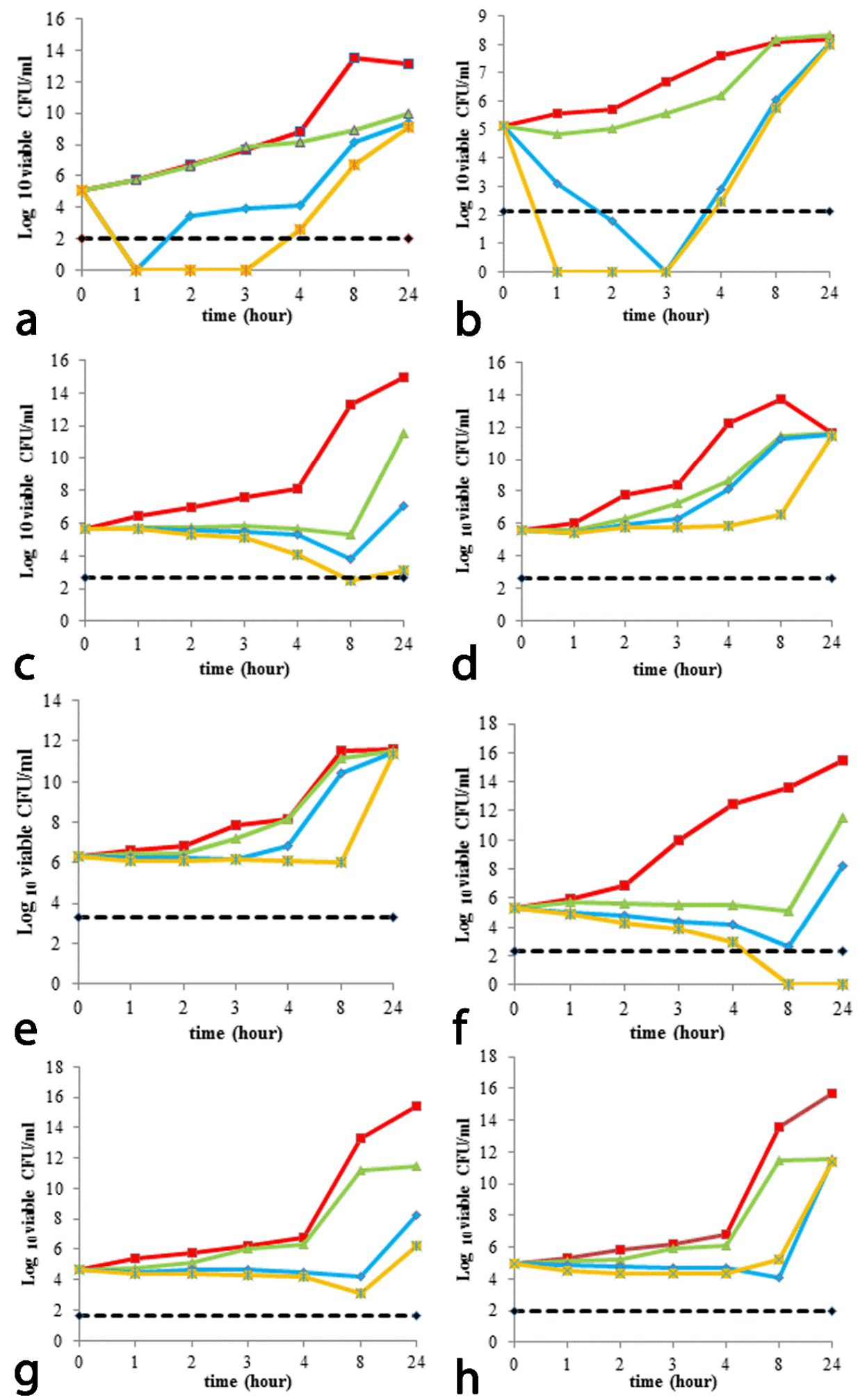

Figure 2. 

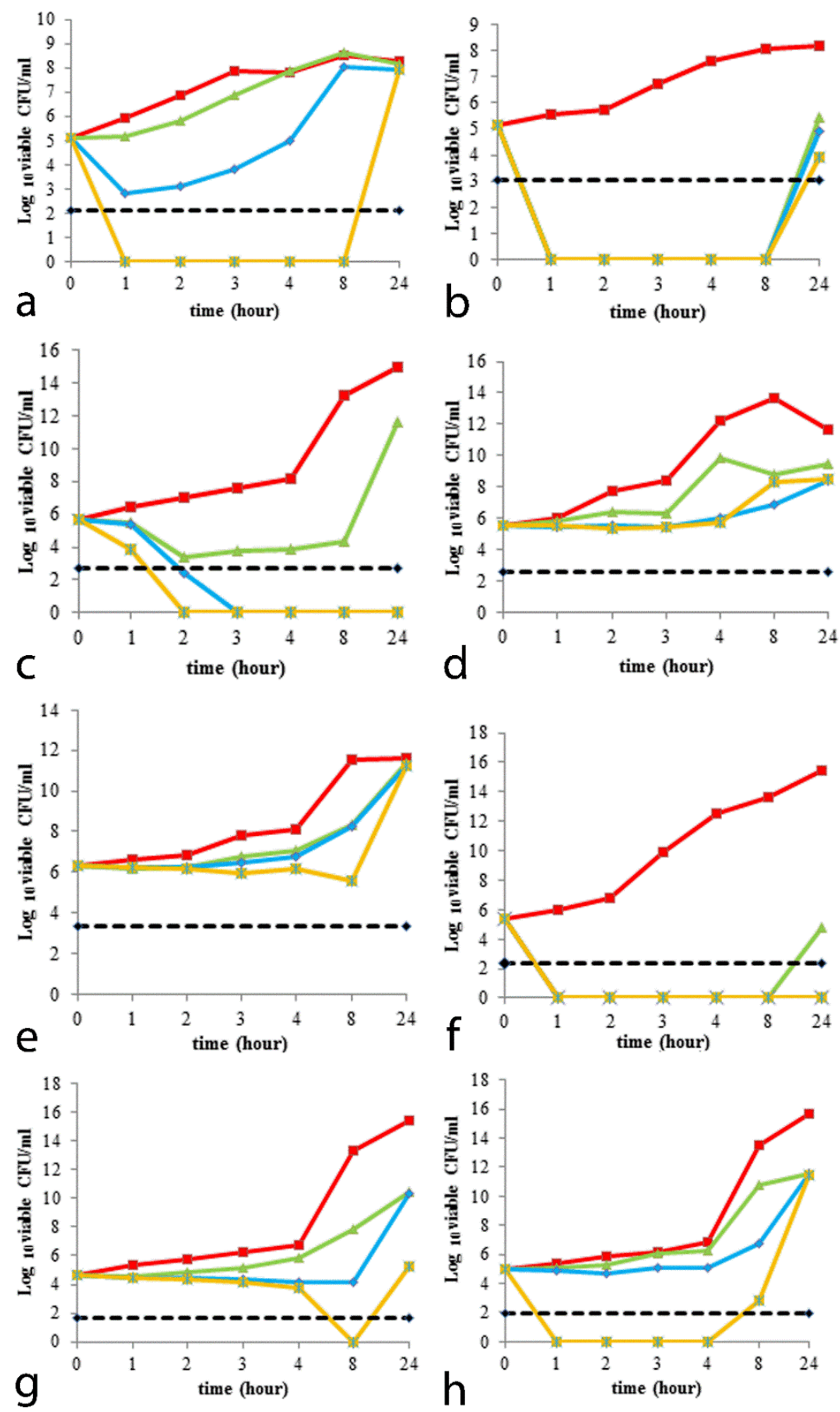

Figure 3. 

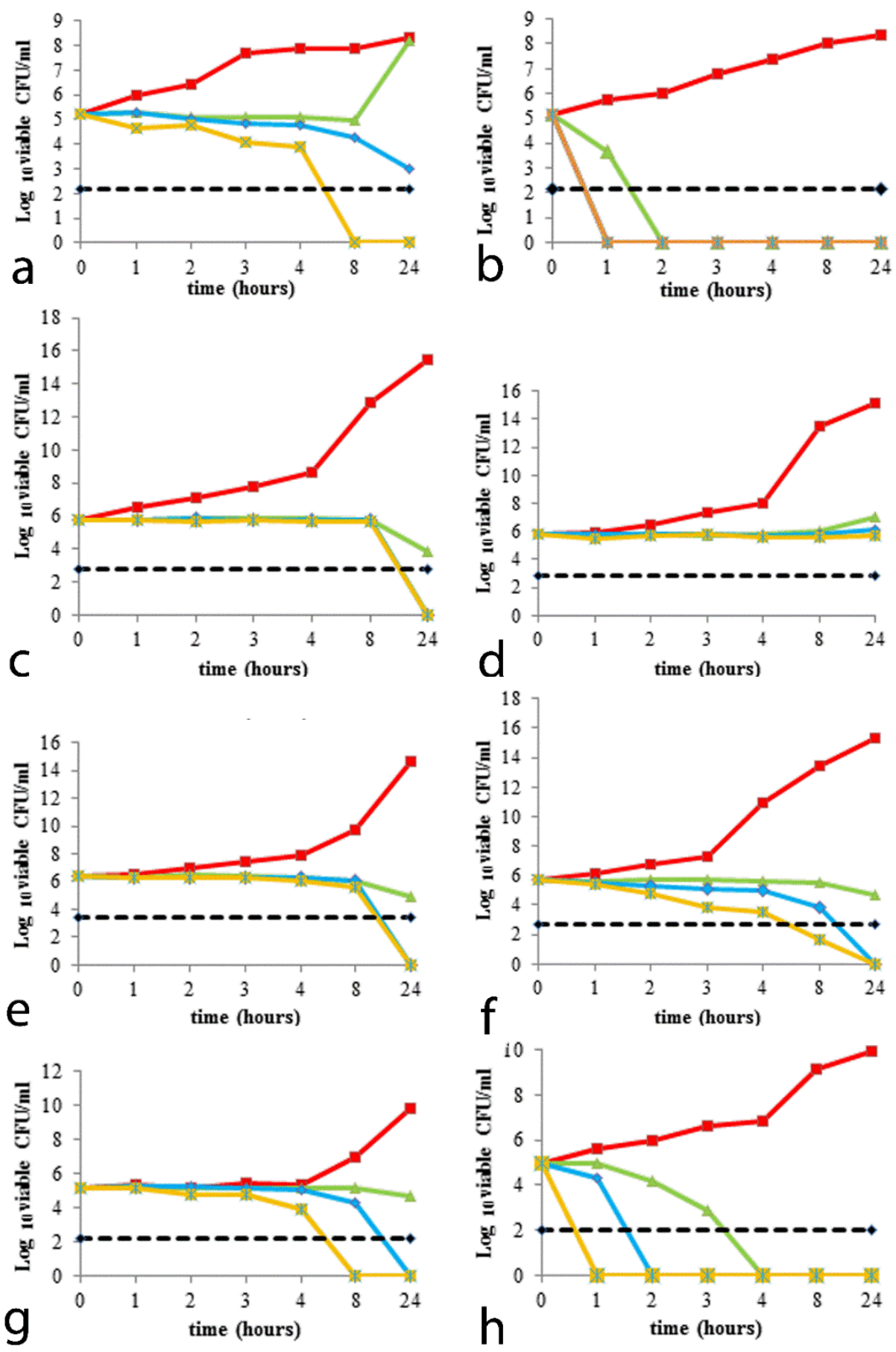

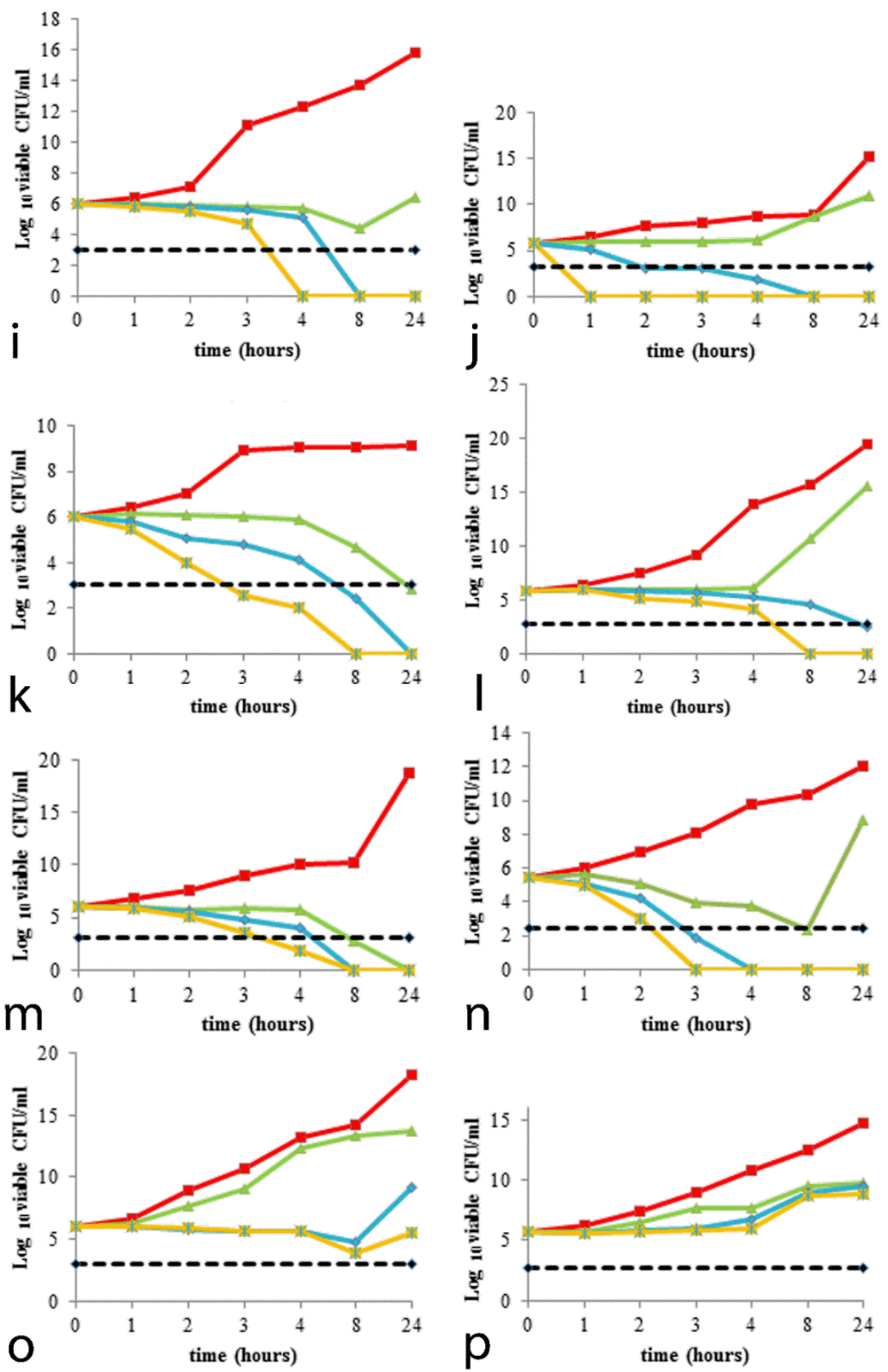

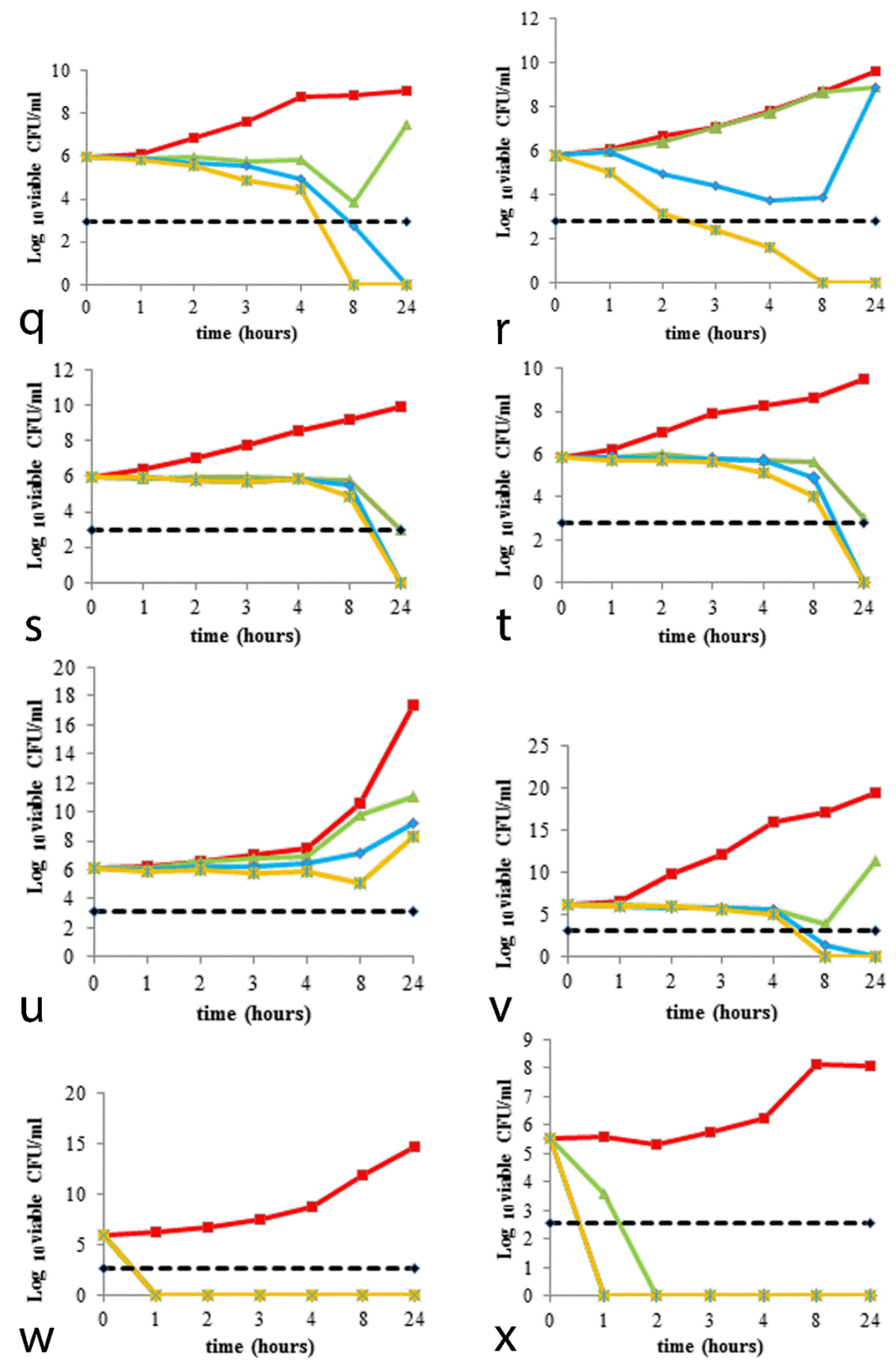

Figure 4. 

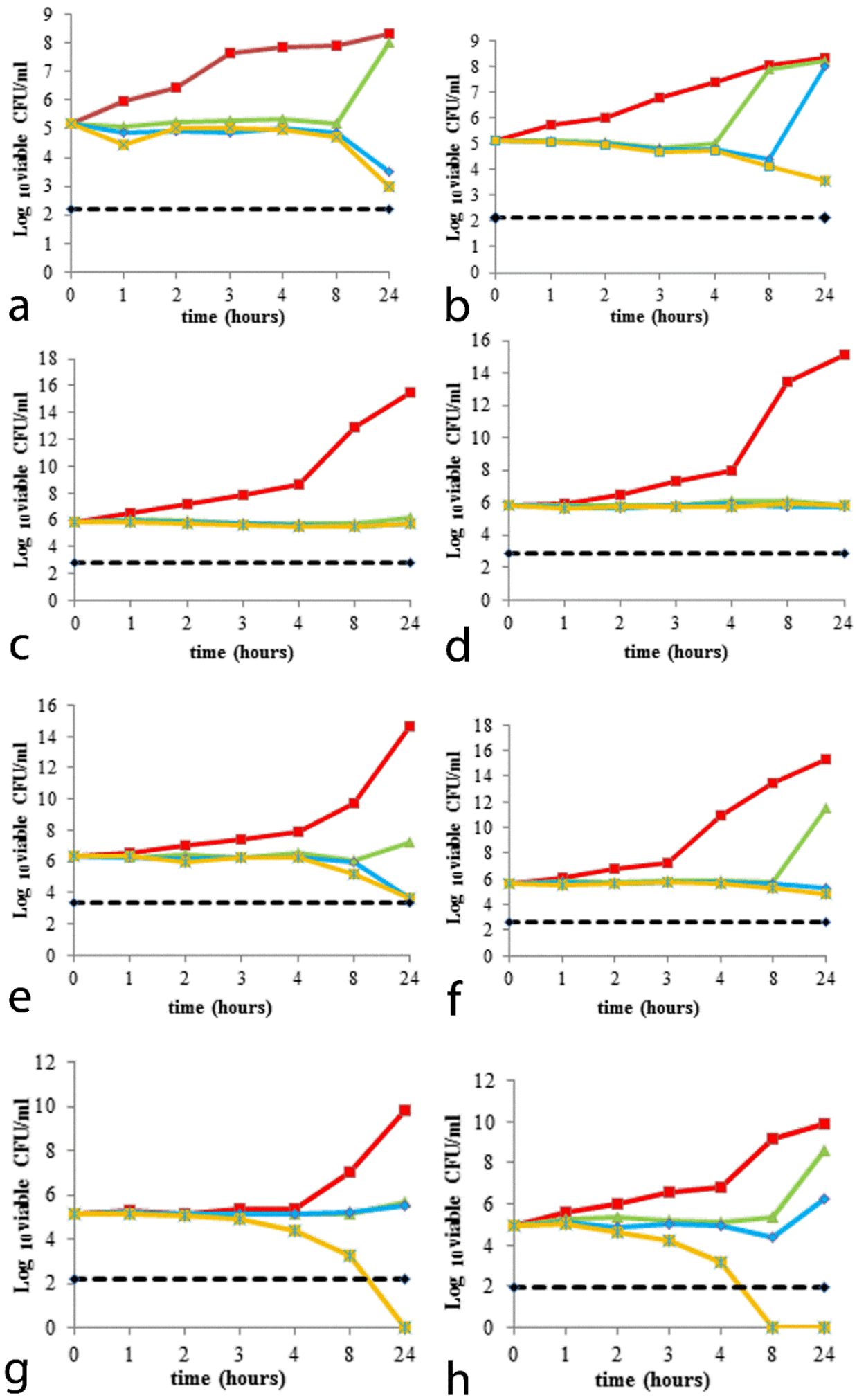

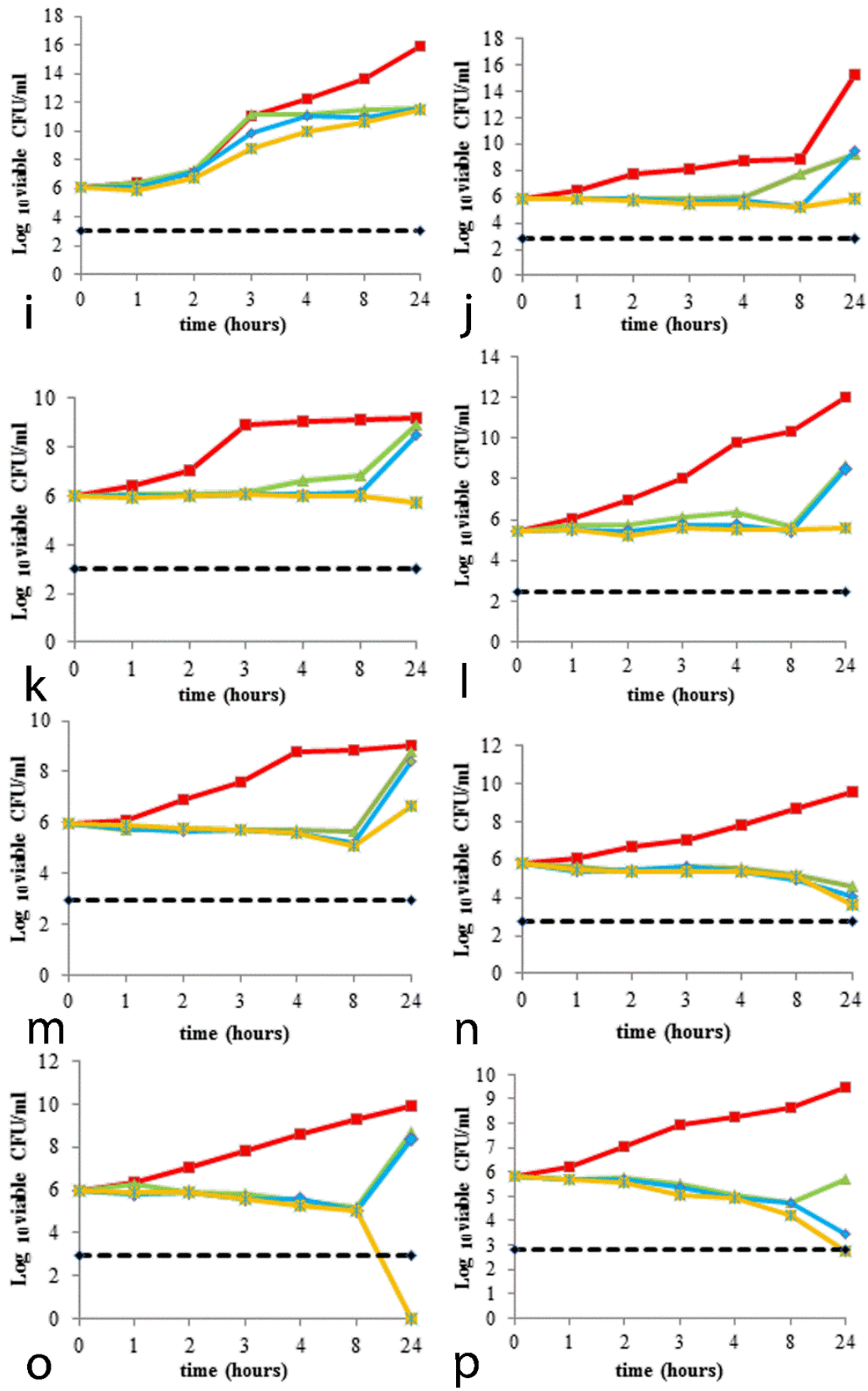

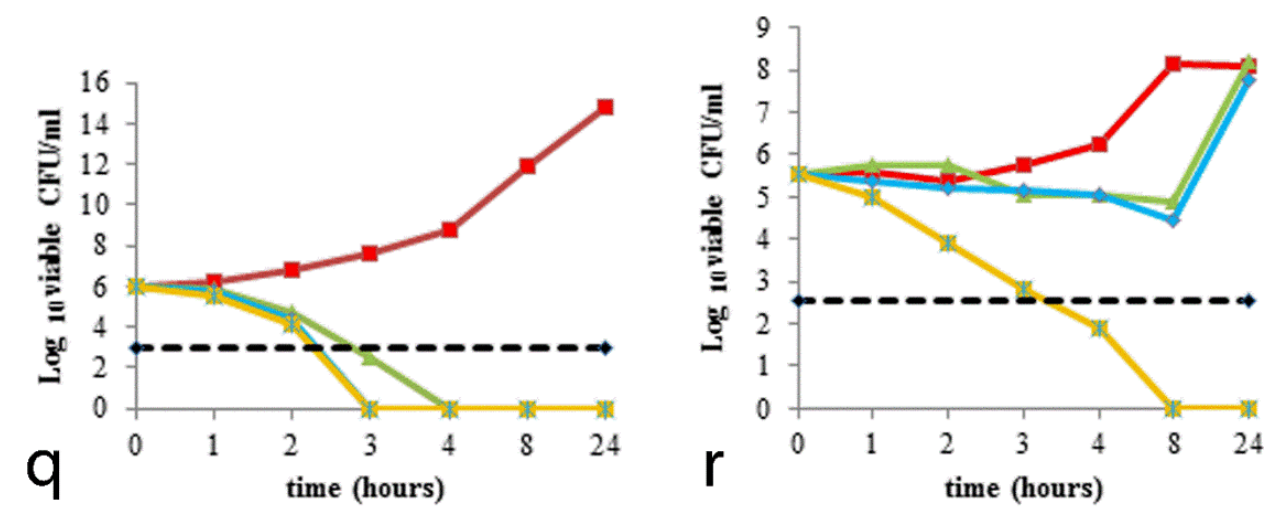

Figure 5. 